Prepared for the U.S. Department of Energy

Under Contract DE-AC05-76RL01830

\title{
Economic and Non-Proliferation Policy Considerations of Uranium Enrichment in Brazil and Argentina
}

\author{
SM Short MR Weimar \\ J Phillips HA Mahy
}

August 2008

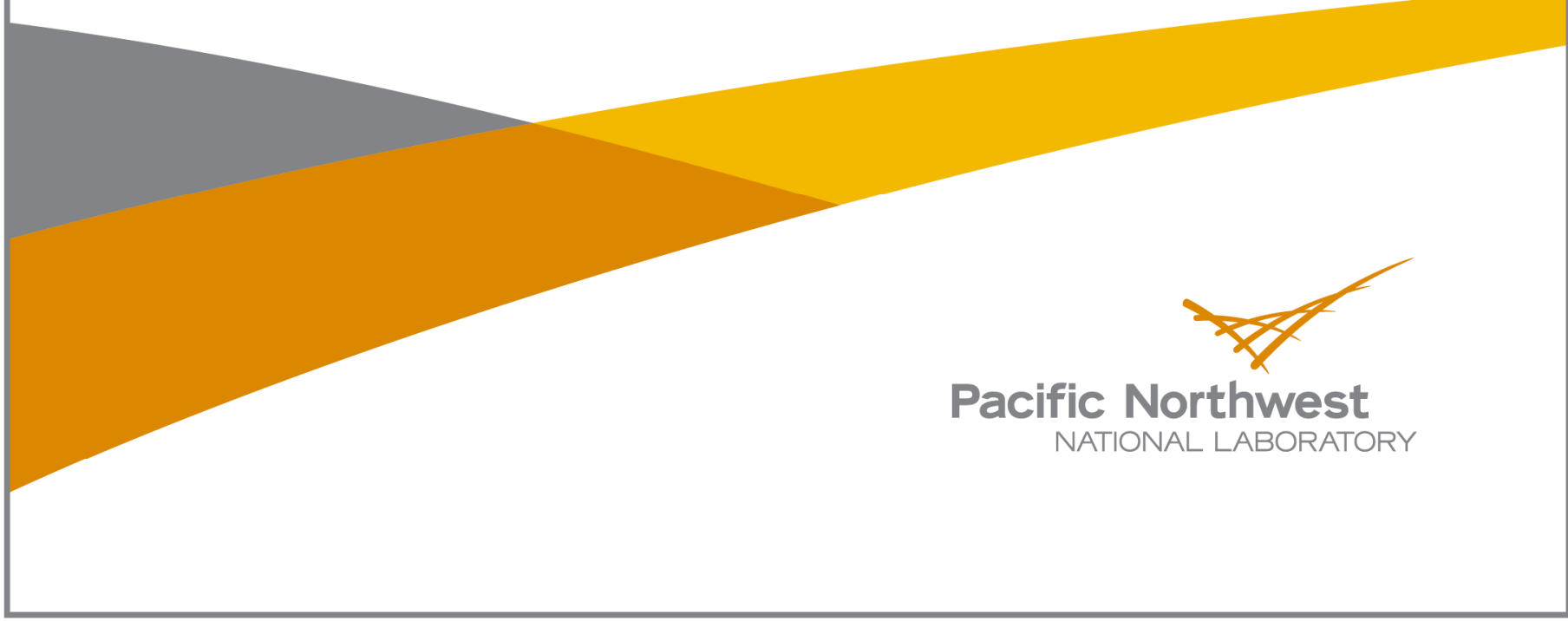




\title{
DISCLAIMER
}

This report was prepared as an account of work sponsored by an agency of the United States Government. Neither the United States Government nor any agency thereof, nor Battelle Memorial Institute, nor any of their employees, makes any warranty, express or implied, or assumes any legal liability or responsibility for the accuracy, completeness, or usefulness of any information, apparatus, product, or process disclosed, or represents that its use would not infringe privately owned rights. Reference herein to any specific commercial product, process, or service by trade name, trademark, manufacturer, or otherwise does not necessarily constitute or imply its endorsement, recommendation, or favoring by the United States Government or any agency thereof, or Battelle Memorial Institute. The views and opinions of authors expressed herein do not necessarily state or reflect those of the United States Government or any agency thereof.

\author{
PACIFIC NORTHWEST NATIONAL LABORATORY \\ operated by \\ BATTELLE \\ for the \\ UNITED STATES DEPARTMENT OF ENERGY \\ under Contract DE-AC05-76RL01830
}

\author{
Printed in the United States of America \\ Available to DOE and DOE contractors from the \\ Office of Scientific and Technical Information, \\ P.O. Box 62, Oak Ridge, TN 37831-0062; \\ ph: (865) 576-8401 \\ fax: (865) 576-5728 \\ email: reports@adonis.osti.gov

\begin{abstract}
Available to the public from the National Technical Information Service, U.S. Department of Commerce, 5285 Port Royal Rd., Springfield, VA 22161 ph: (800) 553-6847 fax: $(703) 605-6900$

email: orders@ntis.fedworld.gov

online ordering: http://www.ntis.gov/ordering.htm
\end{abstract}




\title{
Economic and Non-Proliferation Policy Considerations of Uranium Enrichment in Brazil and Argentina
}

\author{
SM Short MR Weimar \\ J Phillips HA Mahy
}

August 2008

Prepared for

the U.S. Department of Energy

under Contract DE-AC05-76RL01830

Pacific Northwest National Laboratory

Richland, Washington 99352 



\section{Executive Summary}

The nuclear development programs of both Argentina and Brazil have, since the 1970s, been premised on the desire for self-sufficiency and assurance of nuclear fuel supply. While military rivalry and mutual distrust led to nuclear weapons-related development programs in the 1970s and 1980s, both countries have since terminated these programs. Furthermore, the governments of both countries have pledged their commitment to exclusively non-explosive use of nuclear energy and have signed the Non Proliferation Treaty (NPT). Utilizing rights provided for under the NPT, both Argentina and Brazil have nuclear fuel production facilities, with the notable exception of enrichment plants, that provide much of the current indigenous fuel requirements for their nuclear power plants. However, both countries are actively developing enrichment capability to fill this gap. The purpose of this report is to assess the economic basis and non-proliferation policy considerations for indigenous enrichment capability within the context of their desired self-sufficiency and to evaluate possible U.S. government policy options.

\section{Economics, Non-proliferation, and Enrichment Policy}

A major focus of this report is to assess the economic viability of indigenously produced uranium by Argentina and Brazil. However, based on our research into the respective nuclear programs of both of these countries, it is clear that factors other than economics, specifically national security and economic security, are primary drivers for the development of their nuclear policies. For example, Brazil's and Argentina's desire for self-sufficiency in nuclear fuel supply have led each to develop relatively smallscale fuel production facilities to provide fuel for their small power reactor programs, at a cost that is likely substantially higher than just procuring these services from large international suppliers. Another example is that both Brazil and Argentina have uranium resources that they have exploited to fuel their power reactors. Whereas Argentina shut down its one uranium mine/mill in the 1990s because it was much cheaper to import uranium, Brazil continued to operate their one mine/mill, likely at a substantially subsidized cost. A final example is Brazil's efforts to develop a nuclear navy. Fueling a nuclear navy is largely not an economic issue because importing the required highly enriched uranium is prohibited under bilateral agreements, and so Brazil would have to produce this indigenously whatever the cost. The only real economic issue here is whether Brazil is willing to pay the huge cost to develop and maintain a nuclear navy, of which enrichment is one relatively small piece.

This study attempts to identify and assess United States policy options to discourage further development of enrichment capability by Brazil and Argentina, commercial or otherwise, that recognizes these country-specific values. An understanding of their current and future demand for nuclear fuel, and the economics of indigenously produced enrichment services relative to that of international suppliers, is necessary to support the development of a United States strategy to achieve its non-proliferation objectives.

\section{Key Findings}

1. Brazil currently has two operating nuclear power plants (Angra 1 and 2) utilizing pressurized water reactor (PWR) technology. It also has one PWR plant (Angra 3) under construction and scheduled for completion by about 2012. Plans for up to seven additional power plants by 2025 have been announced by Brazil, but no firm commitments have been made yet, nor is there any indication that negotiations with reactor suppliers have been initiated. An enrichment plant having sufficient capacity to fuel Angra 1,2, and 3 would have an annual capacity of about 350,000 separative work 
units (SWU). The production cost of this facility is estimated to be $\$ 125$ per SWU, which is much higher than current contract prices for enrichment services but somewhat less than the current spot price of $\$ 143$ per SWU. However, an enrichment plant having sufficient capacity to fuel Angra 1, 2, 3 and seven additional PWRs would have an annual capacity of about 1.4 million SWU, larger than the current 1.0 million SWU/year Japanese enrichment plant. The production cost of this facility is estimated to be $\$ 80 / \mathrm{SWU}$, which is competitive with the expected production cost of new enrichment plants currently under construction in the United States.

2. Argentina currently has two operating nuclear power plants (Atucha 1 and Embalse) utilizing pressurized heavy water reactor (PHWR) technology. It also has one PHWR (Atucha 2) under construction and scheduled for completion by about 2010. In July 2007, the Argentina and Canadian governments signed an agreement to negotiate terms of a contract for the supply of another PHWR (CANDU 6 reactor) that includes the potential for a second unit. While PHWRs are generally fueled with natural uranium, Argentina has converted Atucha 1 to use slightly enriched uranium (SEU) and is investigating converting their other PHWR reactors to SEU fuel. Even if all of these reactors were converted to use SEU fuel, having up to 1 percent U-235 content, annual enrichment requirements are estimated to be less than 150,000 SWU/year. Enrichment plants of this size are not economical compared to the large enrichment plants currently operating and planned throughout the world.

3. Both Brazil's and Argentina's existing fuel production facilities currently only provide indigenous fuel requirements. Furthermore, the announced plans for capacity expansions at their existing fuel production facilities are adequate to only support planned future indigenous needs. None of the expansion plans for these facilities at this time appear to be adequate to support export of nuclear fuel. ${ }^{1}$

4. Brazil has large natural resources of uranium, currently ranked as the sixth largest in the world. These resources are sufficient to support current and projected indigenous nuclear fuel requirements, as well as to supply potential future uranium exports. Argentina, on the other hand, has few natural uranium resources and currently imports the uranium used by their nuclear power reactors. It has sufficient identified resources only to support its current and planned nuclear power reactors. Unless additional resources are discovered, any further expansion would require importing the necessary uranium.

\section{Conclusions}

1. Electricity production in both Brazil and Argentina is expected to grow at a rate of 3-5 percent per year to support their expanding economies. This translates into approximately $600 \mathrm{MWe}$ additional capacity each year for Argentina and 3,800 MWe each year for Brazil; these rates are more than adequate to justify the nuclear power expansion plans discussed above. However, it is our belief that Brazil will likely not meet its ambitious expansion plan by 2025 because of 1 ) its stated preference to utilize large indigenous untapped hydropower resources if it can resolve outstanding environmental issues $^{2}$ and 2) the fact that Brazil does not appear to have yet initiated discussions with reactor

\footnotetext{
${ }^{1}$ Brazil has held discussions with China on exporting surplus uranium to that country. Brazil's stated preference is to maximize the value of its uranium by exporting enriched uranium. However, the export of uranium is currently prohibited by the Brazil constitution, which would have to be amended before uranium exports could proceed.

${ }^{2}$ This is not meant to imply that construction of seven additional power reactors by 2025 is infeasible. While such a schedule is ambitious, with a Gross Domestic Product that exceeds \$1 trillion per year and a calendar 2007 budget
} 
suppliers for additional capacity (which means seven reactors would need to startup between 2016 and 2025, a rate which few countries have ever sustained). We therefore believe that the total of Brazil's and Argentina's indigenous enrichment requirements will actually be less than 1 million SWU per year in 2025.

2. In February 2008, Brazil and Argentina agreed to establish a bi-national commission to explore further areas of nuclear cooperation between the two nations, with one specific objective of this commission being to establish a bi-national company for uranium enrichment. Given Brazil's modest enrichment requirements and Argentina's small enrichment requirements, the creation of a single co-owned entity to provide enrichment services for both countries makes economic sense. However, unless Brazil's nuclear expansion plans materialize, the enrichment services provided by this company will not be economically competitive with other world suppliers prior to 2025 . On the other hand, the bi-national company could become a spring-board for providing cost competitive enrichment services to other countries if enrichment supply contracts with these countries fill the economic gap. This gap is estimated to be 500,000-1 million SWU per year.

3. Based on past history, sanctions (technology denial) would not be an effective tool to prevent further development of industrial enrichment capacity by either Brazil or Argentina. Given the strong desire for self-sufficiency by these countries, we further doubt that a reliable fuel service and supply (RFS\&S) arrangement could be agreed upon. On the other hand, if a spent nuclear fuel "take-back" arrangement were to be negotiated, we estimate the cost of implementation through 2030 to be between $\$ 500$ million and $\$ 1.8$ billion for Brazilian SNF (overnight cost not accounting for discounting or inflation) for shipment, storage, and direct-disposal in the United States. Corresponding costs for the Argentine SNF is not available. A more practical, and likely less costly, strategy than SNF take-back may be to make an attractive offer on a "technology excluded partnership" in a United States commercial scale enrichment endeavor that includes a "non-compete" agreement. The success of this strategy hinges on making certain that the United States and other enrichment service providers fill all available market share at reasonable cost.

\section{Recommendations}

We do not believe there is a need for the United States to take immediate proactive actions responding to Brazil's and Argentina's enrichment programs. Both countries are in the near term preoccupied with constructing and expanding existing fuel production capacity to meet indigenous fuel production requirements. However, the following activities are suggested:

1. Monitor amendments to Brazil's constitution that would allow export of uranium.

2. Engage Brazil and Argentina to determine if there is any common ground for RFS\&S arrangement as an option.

3. Consider developing criteria for influencing the structure of a multinational enrichment plant in Brazil, should Brazil decide to pursue exporting enriched uranium.

4. Actively develop an improved Safeguards approach and technology for enrichment plants beyond the Hexapartite Safeguards Project (HSP) standard as exercised in Urenco facilities. Work to make this new standard the accepted norm for all operating enrichment plants including any new plants in Brazil or Argentina.

surplus of $\$ 25$ billion, Brazil has the economic and financial means to support this ambitious schedule if it so decides. 



\section{Acronyms and Abbreviations}

$\begin{array}{ll}\text { ABACC } & \text { Agency for Accounting and Control of Nuclear Materials } \\ \text { ACP } & \text { American Centrifuge Plant } \\ \text { AECL } & \text { Atomic Energy of Canada, Ltd. } \\ \text { AP } & \text { Additional Protocol } \\ \text { BR } \$ & \text { Brazilian Reals } \\ \text { EIA } & \text { Energy Information Agency } \\ \text { GDP } & \text { Gross Domestic Product } \\ \text { HEU } & \text { Highly enriched uranium } \\ \text { HSP } & \text { Hexapartite Safeguards Project } \\ \text { IAEA } & \text { International Atomic Energy Agency } \\ \text { INB } & \text { Industrias Nucleares do Brasil } \\ \text { KWU } & \text { Kraftwerk Union } \\ \text { LOF } & \text { Locations Outside Facilities } \\ \text { NEF } & \text { National Enrichment Facility } \\ \text { NPT } & \text { Nuclear Non-Proliferation Treaty } \\ \text { NNWS } & \text { Non Nuclear Weapons State } \\ \text { NWS } & \text { Nuclear Weapon State } \\ \text { OECD } & \text { Organization for Economic Cooperation and Development } \\ \text { PHWR } & \text { pressurized heavy water reactor } \\ \text { PWR } & \text { pressurized water reactor } \\ \text { QAP } & \text { Quadripartite Additional Protocol } \\ \text { QCSA } & \text { Quadripartite Comprehensive Safeguards Agreement } \\ \text { R\&D } & \text { research and development } \\ \text { RAR } & \text { reasonably assured resources } \\ \text { RFS\&S } & \text { reliable fuel services and supply } \\ \text { SEU } & \text { slightly enriched uranium } \\ \text { SNF } & \text { spent nuclear fuel } \\ \text { SWU } & \text { Separative Work Unit } \\ \text { tU } & \text { tonnes Uranium } \\ \text { USEC } & \text { United States Enrichment Corporation } \\ \text { USG } & \text { U.S. Government } \\ & \end{array}$





\section{Contents}

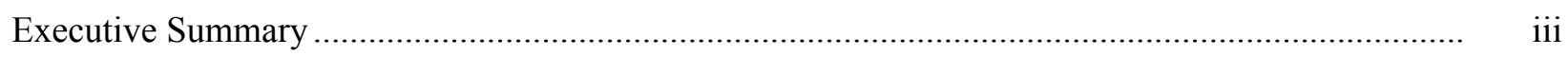

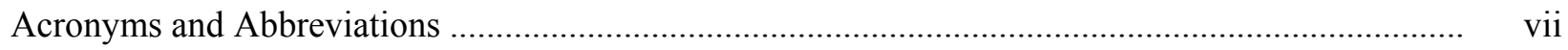

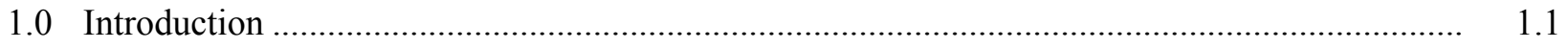

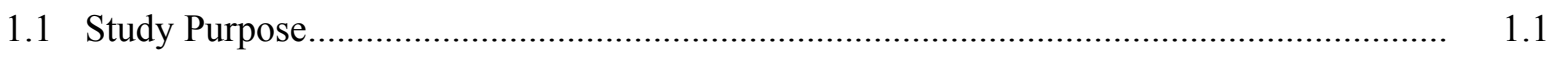

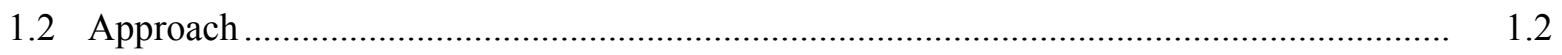

2.0 Nuclear Development Background and Nonproliferation ................................................... 2.1

2.1 Historical Context for Development of Uranium Enrichment Technology ........................ 2.1

2.2 Implications of the Additional Protocol ..................................................................... 2.2

2.3 Brazil Policy Options Regarding the Additional Protocol .............................................. 2.3

2.4 Argentina Policy Options Regarding the Additional Protocol .......................................... 2.4

3.0 Civilian Nuclear Infrastructure ..................................................................................... 3.1

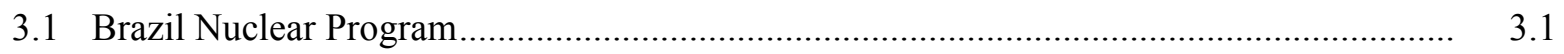

3.2 Argentina Nuclear Program ................................................................................. 3.3

4.0 Energy Resource Endowments and Constraints ............................................................ 4.1

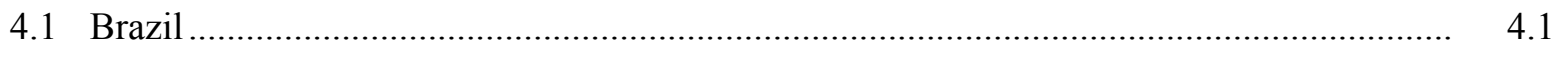

4.1.1 Projected Electricity Generation in Brazil........................................................ 4.1

4.1.2 Potential Issues with Expanding Generating Capacity........................................ 4.1

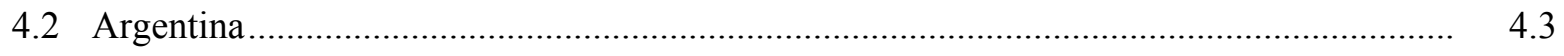

4.2.1 Projected Electricity Generation in Argentina .................................................. 4.3

4.2.2 Potential Issues with Expanding Generating Capacity.......................................... 4.3

5.0 Current Costs for Enrichment Services .......................................................................... 5.1

5.1 Cost Comparisons for Established Enrichment Facilities .............................................. 5.1

5.2 Costs of the Current Facility and Future Expansion of Resende Plant ............................. 5.1

5.3 Delineation of Argentina Costs for Development of Enrichment Services......................... 5.2

6.0 Demand and Supply of Enrichment Services .............................................................. 6.1

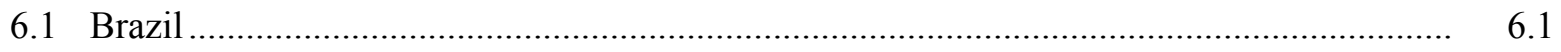

6.1.1 National LEU Quantities to Meet Domestic Requirements ................................. 6.1

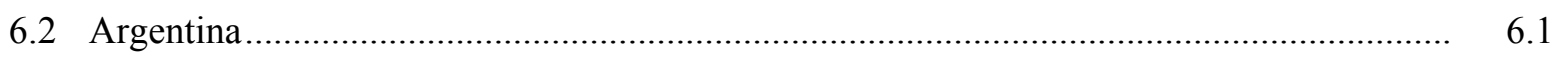

6.2.1 National LEU Quantities to Meet Domestic Requirements .................................. 6.1

6.3 Regional Demand for Enrichment Services ............................................................. 6.2

6.4 World Demand for Enrichment Services .................................................................. 6.2

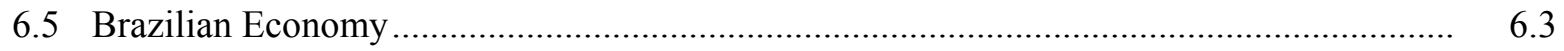

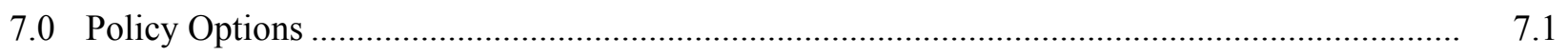

7.1 Economic Sanctions and Technology Denial............................................................ 7.1

7.2 Reliable Fuel Services and Supply ........................................................................... 7.2

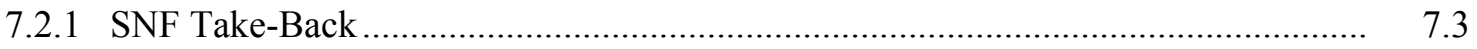


7.2.2 Regional Enrichment Center .....................................................................

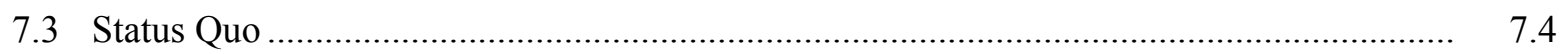

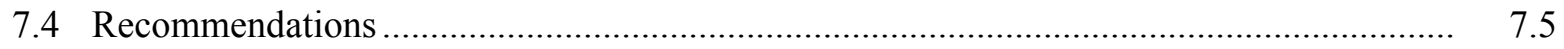

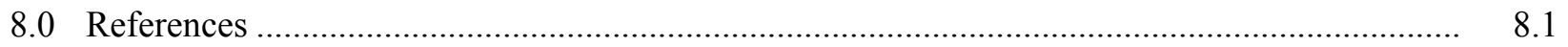

\section{Figures}

4.1 Current and Projected Electricity Generation in Brazil ...................................................... 4.2

4.2 Current Electricity Generation in Argentina .....................................................................

\section{Tables}

3.1 Comparison of Fuel Production Requirements and Current/Planned Facility Capacity for Brazil.

3.2. Comparison of Fuel Production Requirements and Current/Planned Facility Capacity for

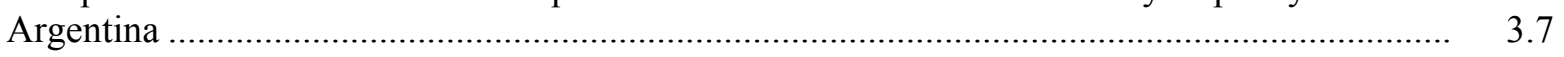

5.1 Estimated Costs of Brazilian Enrichment Different Size Plants .............................................. 5.2

6.1 Current Suppliers and Market Share, Projected Market Share ............................................. 6.3

7.1 Estimated Cost for Take-Back of Brazilian SNF .............................................................. 


\subsection{Introduction}

Both Brazil and Argentina have a well-established nuclear power infrastructure, including two operating nuclear power plants each, indigenously designed and constructed research reactors, and associated fuel production facilities for both research and power reactors. Furthermore, both countries have unfinished power reactors and have recently announced modest expansion plans to complete these plants and construct several additional power reactors over the next 20 years. Included in these plans is expansion of capacity of their fuel production facilities to supply the fuel required for these new reactors. Development and expansion of uranium enrichment capacity is also included in these plans.

Brazil and Argentina have renounced the development of nuclear weapons, ratified the Treaty of Tlatelolco declaring Latin America a nuclear weapons free zone, and signed the Nuclear Non Proliferation Treaty (NPT), thus opening their facilities to full International Atomic Energy Agency (IAEA) safeguards. The uranium enrichment programs of both countries are openly declared facilities subject to these IAEA safeguards.

Both countries also have a declared policy of energy independence. As such, each has invested heavily in developing existing operating nuclear power and fuel production facilities. However, by international standards, these programs are relatively small. A relevant issue then is whether the fuel production requirements, and specifically uranium enrichment requirements, for these countries is of sufficient economy-of-scale to support an economically sustainable indigenous fuel production industry.

\subsection{Study Purpose}

The purpose of this study is to address sustainability of an indigenous fuel enrichment industry by performing an economic assessment of Brazil's and Argentina's nuclear energy programs. The intent of this evaluation is to help policymakers understand the economic drivers and barriers to Brazil's and Argentina's development of self-sufficiency in civil and naval non-explosive nuclear power programs, concentrating on the front end of the fuel cycle. The study also evaluates to what extent Brazil's and Argentina's enrichment programs pose a proliferation concern and how their example will impact other countries considering acquisition of nuclear power and considering whether or not to invest in enrichment capabilities.

The study focuses on economic and political factors associated with the Brazilian enrichment facility at Resende in particular. The study evaluates the economic credibility of the enrichment facility as a component of Brazil's civil and naval power programs, both directly and in comparison to international norms. The study also assesses whether Brazil's and Argentina's investments in their domestic enrichment programs makes economic sense for the current and projected scale of their nuclear power programs. The economic assessment evaluates the enrichment programs for these countries from three different perspectives: 1) providing self-sufficiency for the civil and non-explosive naval requirements; 2) becoming a regional supplier of enrichment services as nuclear power grows to meet energy demands; and 3) as an international supplier of enrichment services to enhance the value of Brazil's relatively large endowment of natural uranium resources. Consideration is also given to specific policies that may be employed to mitigate proliferation concerns, including economic incentives (regional, energy security, and/or technology substitution) or disincentives (sanctions) under both strengthened nonproliferation and counter proliferation. 


\subsection{Approach}

The analysis approach entails:

- First, provide a historical background for nuclear development in Brazil and Argentina. The background details their past positions and how their history has led them to the current position to not sign the IAEA Additional Protocol.

- Second, estimate the demand for uranium enrichment services by forecasting current and future needs for domestic civil and naval nuclear fuel requirements. Correspondingly, estimate the total uranium requirements to support these programs and compare to known indigenous uranium resource endowments.

- Third, assess the availability of other indigenous resource endowments (e.g., hydropower, coal, oil) and their potential for providing future projected electricity requirements.

- Fourth, determine the unit cost and variable cost to enrich uranium at the Resende Enrichment Plant. Assess the difference between Brazilian enrichment service costs and current and future international prices to provide an assessment of the value of a) energy security/independence and b) a hedge against disruption of enrichment services.

- Fifth, compare current and projected capacities of existing uranium enrichment service providers to the global demand for these services. Examine potential barriers to obtaining future enrichment services contracts.

- Sixth, assess the economic and policy implications of three scenarios: 1) providing for selfsufficiency in uranium enrichment services, 2) becoming a regional supplier of enrichment services as nuclear power grows to meet energy demands, and 3) becoming an international supplier of enrichment services. 


\subsection{Nuclear Development Background and Nonproliferation}

Both Brazil and Argentina have had nuclear technology development programs for several decades and currently have active programs for developing uranium enrichment technology. Both countries took advantage of the Atoms for Peace program to jump-start their nascent nuclear technology programs. Both countries have ratified the Non-Proliferation Treaty (NPT) and have a Comprehensive Safeguards Agreement (CSA) in force. However, neither country has signed the IAEA Additional Protocol (AP). This section provides historical background for the nuclear development programs (including enrichment) of both countries and assesses the implications of the AP to both countries' efforts.

\subsection{Historical Context for Development of Uranium Enrichment Technology}

The Brazilian and Argentine nuclear programs have similar development histories. Brazil's program, started somewhat earlier than Argentina's due to the large deposits of uranium discovered in the 1930s. Uranium ore was provided to the United States in the 1940s/1950s in exchange for transfer of nuclear technology. Both Brazil and Argentina were provided with their first research reactors in the late 1950s by the United States under the Atoms for Peace program. Peaceful nuclear power programs were developed in both countries through the 1960s, culminating with the award of construction contracts for the first nuclear power plant in each country. The contract for Atucha 1 in Argentina was awarded in 1968, and a contract for Angra 1 in Brazil was awarded in 1971.

However, both countries soon became frustrated with the restrictions nuclear supplier countries placed on the transfer of nuclear technology since neither were signatories of the NPT. Specifically, Brazil was dissatisfied with the deal they got from the United States for the supply of Angra 1 because 1) it barred the transfer of United States nuclear technology to Brazil, 2) it made Brazil dependent on U.S. uranium for the reactor, and 3) it required that all Brazilian nuclear facilities be safeguarded by the IAEA. In response, Brazil concluded an agreement in 1975 with the Federal Republic of Germany for the supply of eight 1300-MWe(net) nuclear units, as well as a commercial uranium enrichment facility, a pilot plutonium reprocessing plant, and joint development of enrichment technology. However, U.S. opposition to the agreement ultimately resulted in the imposition of stringent safeguards on any transferred technology. The deal eventually ended with only one of the reactors completed (Angra 2) and one reactor partially completed (Angra 3).

Similarly, Argentina chose to go with a natural uranium-fueled reactor for Atucha 1, specifically to avoid reliance on U.S. enriched uranium. For similar reasons, Argentina concluded an agreement with Canada for the supply of a second uranium-fueled reactor (Embalse) and which included transfer of nuclear technology. However, Canada reneged on the technology transfer portion of the deal in the aftermath of the 1974 nuclear test in India.

Frustrated by these restrictions and seeking technical autonomy, Brazil and Argentina were opposed to the NPT. Both countries initiated secret programs to further develop their indigenous nuclear capabilities. Both pursued mastery of the entire nuclear fuel cycle, but development of uranium enrichment technology was a main focus of their research efforts. Due to their intense rivalry and mutual distrust of one another, the military rulers of both countries subsequently initiated nuclear weapons 
development efforts within the confines of these secret programs. Only after the restoration of civilian rule in the mid-1980s was the existence of these secret programs publicly revealed and terminated, and the nuclear rivalry between these two countries diffused.

On November 28, 1990, Brazil and Argentina signed the Argentine-Brazilian Declaration on Common Nuclear Policy of Foz do Iguaçu in which both governments pledged their commitment to an exclusively peaceful use of nuclear energy and established a Common System for Accounting and Control of Nuclear Materials. Subsequently, on July 18, 1991, the presidents of Brazil and Argentina signed the Agreement Between the Federative Republic of Brazil and the Argentine Republic on the Exclusively Peaceful Use of Nuclear Energy, or Bilateral Agreement, which created the BrazilianArgentine Agency for Accounting and Control of Nuclear Materials (ABACC). ABACC provides on-site inspections of nuclear facilities in Argentina and Brazil and maintains an inventory of nuclear material in each country.

In December 1991, Brazil, Argentina, ABACC and the IAEA concluded the "Quadripartite" Comprehensive Safeguards Agreement (QCSA), which provides for full-scope IAEA safeguards of Argentine and Brazilian nuclear installations. Consisting of obligations identical to those under the NPT, this agreement also allows the two countries to retain full rights over any "technological secrets" and to develop nuclear energy for naval propulsion (QCSA Article 13).

With their rights firmly established within the bounds of the NPT, ${ }^{3}$ both Argentina and Brazil have been actively developing indigenous uranium enrichment technology. Over the years, Brazil has stated its ongoing interest in nuclear naval propulsion on many occasions. It has been reported that Brazil's Navy has expended \$1.1 billion on nuclear programs from 1979 through 2007, supporting nuclear power generation, nuclear naval propulsion, and the nuclear fuel cycle (Pesquisa FAPESP 2007). ${ }^{4}$ It was also reported that Brazil will expend an additional 1 billion Brazilian Reals over the next eight years on its Navy nuclear program. The current centrifuge facilities at Resende are in fact financed by Brazil's navy and the technology development was done under navy programs. The first two centrifuges of the Resende Enrichment Facility (REF), having a production capacity of about 4,000 separative work units (SWU)/year, were commissioned in 2006 (Terça-feira 2006.). Expansion to provide all of the enrichment requirements for Brazil's commercial nuclear power plants is currently underway. Argentina's uranium enrichment development program is much less ambitious. An experimental enrichment facility utilizing gaseous diffusion technology was re-commissioned in 2007.

\subsection{Implications of the Additional Protocol}

Neither Argentina nor Brazil has signed the IAEA Additional Protocol (AP) granting the IAEA expanded inspection rights to their nuclear facilities. Both countries have declared their opposition to the AP because of their perception that past enforcement of the NPT has discriminated against Non-Nuclear Weapons States (NNWS) by focusing on the non-proliferation clauses of the NPT while not enforcing the disarmament clauses that apply to the Nuclear Weapons States (NWS). Both have stated that they will only consider signing the AP after the NWS have made concrete progress toward nuclear disarmament.

\footnotetext{
${ }^{3}$ Argentina ratified the NPT in 1995 followed by Brazil in 1998.

${ }^{4}$ Of the $\$ 1.1$ billion, $\$ 300$ million was expended on the nuclear naval propulsion project.
} 
However, this stated reason for opposition to the AP also acts as an argument of convenience, allowing Brazil and Argentina to avoid inspection of their facilities and avoiding conflict with the QCSA. Article 2 of the AP requires that all research and development (R\&D) on nuclear reactors, conversions, fuel fabrication, etc., "not involving nuclear material," must be declared, and locations and "a description of the scale of operations for each location engaged in the activities specified in Annex I to this Protocol" specified, and made accessible for IAEA complementary inspection access with measures including location specific environmental sampling. ${ }^{5}$ Many of the technologies, including reactors, critical elements of fuel fabrication and fuel handling, enrichment, are captured under Annex I of the AP. As a result, under the AP, the manufacturing complex underlying a classified Brazilian naval propulsion program, the centrifuge manufacturing complex, and R\&D capabilities and facilities would, to a large extent, be captured and subject to inspection. However, these assets are not captured for the purpose of inspection under the QCSA.

Given that Article 1 of the AP articulates that the AP supersedes the CSA should they be found in disagreement, these difficulties may create a significant impasse in adding the AP to the QCSA since nonproscribed nuclear military activities are already underway in Brazil. It could be argued that managed access allowed under the AP could be used to protect classified information; however, environmental sampling and other inspection measures would create a significant risk of revealing classified information in a naval propulsion R\&D and manufacturing complex. Moreover, nuclear material under QCSA Article 13, which is not under active IAEA Safeguards, would most likely be at an AP declarable location(s), though possibly detectable by IAEA inspections.

\subsection{Brazil Policy Options Regarding the Additional Protocol}

Accept Unmodified AP. It seems inconceivable that the detailed locations and activities of a naval propulsion program would be declared by a State Party and made available for IAEA inspection. Under such conditions, therefore, acceptance of the unmodified AP could create confusion on how to practically exercise Brazil's Article 13 rights under the QCSA if they elected to do so. On the other hand, it would seem that so long as the R\&D program had the nuclear material under Article 13 on location, the activities and facilities would not be captured by AP Article 2. However, this would seem a very tenuous strategy to pursue since a classified naval propulsion R\&D program is an expansive effort and the QCSA Article 13 material could not be associated with the entire enterprise in any practical manner. The presumption of the phrase "not including nuclear material" in AP Article 2 is that if it includes nuclear material, it must be captured under the CSA and/or the exempted material clauses. However, QCSA Article 13 material would not be under active IAEA Safeguards and its location would presumably be unknown to the Agency. Exploiting such a loop hole as a matter of practice might call into question a State Party's scrupulous compliance bona fides. Moreover, such a tortuous approach to protecting R\&D would not exempt the naval propulsion program manufacturing complex or "locations outside facilities (LOFs) where nuclear material is customarily used" from declaration and inspection under the AP.

Reject AP. Since the Quadripartite was done in 1991 and the NPT was not ratified by Brazil until 1998, it is reasonable to presume that Brazil sees Article 13 as its current legal obligation (no more, no less) and would not relinquish the point or confuse its possible future implementation with an AP. Moreover, recent news reports indicate that Brazil has manufactured many of the large components for

\footnotetext{
${ }^{5}$ Annex I is a list of key fuel cycle technologies that refers to Annex II which defines those technologies.
} 
a 48-MW reactor for naval propulsion purposes and that construction should be completed by 2014 (Pesquisa FAPESP 2007). ${ }^{6}$ If those reports are true, Brazil may need highly enriched uranium (HEU) to complete its testing and it will not be able to import that material since bilateral agreements require strictly peaceful use as opposed to non-explosive use. Furthermore, if Brazil produces HEU for such a reactor, it may exercise Article 13 to protect the details of the reactor, its fuel design, and associated military nuclear infrastructure.

Accept Modified AP. It would seem that the IAEA Secretariat would discourage exercise of QCSA Article 13 as much as possible as exercise of the article could have significant bilateral fallout. However, State Parties are jealous of their rights and defend them. If a Quadripartite AP (QAP) had a national security exclusion for programs related to QCSA Article 13, that might resolve the issue (if that is indeed the ultimate sticking point on a QAP). However, that means Brazil and Argentina would have a different AP than all other NNWS, creating a significantly awkward precedent for future AP implementation. If Brazil and Argentina were to gain extra rights under their AP, it might negatively impact a considerable number of other negotiations and would certainly create lasting acrimony in the international community (particularly among NNWS with an AP already in force). It would essentially make it impossible for the IAEA to draw credible conclusions regarding the absence of undeclared nuclear activity, given that undeclared/uninspected nuclear activity is directly implied by exercise of QCSA Article 13 and by any national security exclusion offered to exempt those activities from inspection under a QAP.

\subsection{Argentina Policy Options Regarding the Additional Protocol}

While the intense nuclear past rivalry between Argentina and Brazil has been significantly diffused, Argentina does consider itself an equal power to Brazil. Therefore, while Argentina does not currently have a known program for developing naval nuclear propulsion, it is to be expected that they will demand parity with Brazil with regards to the AP. Argentina will therefore most likely demand the same special conditions or exclusions granted to Brazil in the AP, if any. Given that an AP is an amendment to an existing CSA, and Argentina is under the QCSA with Brazil as a partner, Argentina may not be able to legally sign and ratify an AP independent of Brazil, but would have to withdraw from the QCSA and conclude a separate CSA with the IAEA so that it could also conclude a separate AP as an amendment. Given that Argentina and Brazil's regional security interests are tightly conjoined, it is very unlikely that either party would seek to conclude separate arrangements.

\footnotetext{
${ }^{6}$ The large components that have been manufactured include the reactor pressure vessel, pressurizer, condenser, turbine, and propulsion turbogenerators.
} 


\subsection{Civilian Nuclear Infrastructure}

Brazil and Argentina have the most advanced nuclear capabilities and infrastructure in Latin America. While each sustains relatively sophisticated nuclear programs, the technological focus of their programs are different. Pressurized light-water reactor (PWR) technology is the current technology of choice for existing Brazilian commercial power reactors, while pressurized heavy-water reactor (PHWR) technology is utilized in existing Argentine commercial power reactors. Each has developed fuel production capabilities to provide the fuel for these power reactors. The motivation for indigenous capability is principally driven by the desire for self-sufficiency and independence from suppliers perceived as having been unreliable in the past. Each country has well established nuclear research programs to support further commercial nuclear power development and other nuclear ambitions (e.g., isotope production, research reactor development). This section provides a brief summary of Brazil's and Argentina's civilian nuclear power program, and associated fuel fabrication facilities.

\subsection{Brazil Nuclear Program}

Brazil currently has two operating nuclear power reactors: 1) Angra 1, a 626-MWe PWR supplied by Westinghouse Electric Co. that began commercial operation in 1985 and 2) Angra 2, a 1270-MWe PWR supplied by Siemens-Kraftwerk Union (KWU) that began commercial operation in 2001. Construction on a third PWR, Angra 3 (essentially a twin of Angra 2), was initiated but never completed. The Brazilian government announced in June 2007 that it would finance the completion of this plant (WNA 2007), with operation not expected until 2012 or later (PROS 2007).

Various representatives of the Brazilian government have made statements regarding the future expansion of nuclear power in Brazil. Plans indicated in recent statements range from the construction of four new plants after 2015 (WNA 2007) to the construction of seven new plants by 2025 (Mercopress 2006). However, the government of Brazil has not yet publicly announced concrete decisions regarding construction of additional power plants, as these plans will be (to some extent) dependent upon the ability to proceed with the construction of new hydroelectric power plants. Two major hydroelectric projects are currently being delayed by environmental issues (NEI 2007). Using available information on the uranium requirements for Angra 1 and 2, and assuming that Angra 3 and the projected seven future plants by 2025 will be similar in technology and scale to Angra 2, annual nuclear fuel production requirements are estimated and summarized in Table 3.1 for each step in the fuel production cycle ${ }^{7}$.

Brazil has successfully mastered the technology for all steps of the fuel fabrication cycle, and has industrial scale facilities for most of these steps. All nuclear fuel production facilities in Brazil are owned by the government.

Summary. Table 3.1 at the end of this section provides a comparison of the fuel production requirements for Angra 1 and 2 and the existing/planned capacity of Brazil's commercial fuel production

\footnotetext{
'It is the authors' opinion that this rate of expansion is unlikely given 1) Brazil's large untapped hydropower resources and 2) the reality that commitments for the first of these additional reactors would need to be made within the next couple of years to stay on the announced plan. A more achievable expansion plan would be 2 to 3 additional reactors by 2025 .
} 
facilities. It also provides an estimate of the fuel production requirements for planned additional nuclear power plant capacity. For this analysis, we assume that Brazil will proceed with the approved Angra 3 plant and the seven additional plants by 2025 (which are all assumed to be Angra 2-type reactors in this analysis). These results reveal the following:

- Current mined uranium capacity is inadequate to fuel Angra 1 and 2, making Brazil a net uranium importer. The planned increase in capacity to $680 \mathrm{tU} / \mathrm{yr}$ by 2012 may just be adequate to fuel Angra 1,2 , and 3. The planned increase in production to $1,200 \mathrm{tU} / \mathrm{yr}$ will only provide about 40 percent of the mining/milling capacity required to fuel all current and projected reactors in 2025.

- Brazil currently has no industrial-scale uranium conversion facilities and public announcements only provide vague indications of Brazil's intent to eventually construct conversion capacity (possibly by 2014). However, the design/construction of an industrial-scale facility would not be expected to pose a difficulty for Brazil given their established capability for conversion of $\mathrm{UF}_{6}$ to $\mathrm{UO}_{2}$.

- Planned enrichment capacity by 2010 will only be sufficient to provide approximately 60 percent of Angra 1 and 2 requirements. The planned increase in capacity will be sufficient to provide 100 percent of Angra 1, 2, and 3 requirements. Increasing capacity by an additional factor of 4 would be required to fuel the seven additional units planned by 2025 .

- Brazil has sufficient existing fuel fabrication capacity (including $\mathrm{UO}_{2}$ powder and pellet production) to fuel Angra 1, 2, and 3. Less than a factor of three increase in capacity would be needed to fuel the seven additional units planned by 2025 .

Significantly, if Brazil implements the planned expansion in nuclear power and expands the capacity of their fuel production complex to support this expansion, its fuel production facilities will have capacities that are approaching those that already exist or are planned throughout the world. Specifically, the planned nuclear power expansion will require about 1.4 million SWU, which is larger than the capacity of the Rokassho enrichment plant in Japan and only about half the capacity of the 3 million SWU National Enrichment Facility being built by URENCO in the United States.

Uranium Mining/Milling. Brazil has large natural resources of uranium, currently ranked as the sixth largest in the world with reasonably assured resources (RAR) of 157,700 tU recoverable at a cost of less than US\$80 per kgU (OECD 2005). Uranium is currently being mined at just one facility, Lago Real, where the mined uranium is also milled into yellowcake $\left(\mathrm{U}_{3} \mathrm{O}_{8}\right)$. The production capacity of this plant is 340 tonnes Uranium per year (tU/yr). This is sufficient to provide about 80 percent of Angra 1 and 2 requirements of $430 \mathrm{tU} /$ year (see Table 3.1). However, Brazil has plans to increase uranium production at Lago Real to 640 tU/year over the next few years (INB 2007d). In addition, in June 2006, Brazil announced plans to expand uranium production to $1200 \mathrm{tU} / \mathrm{yr}$ by developing other natural uranium deposits (NEI 2007). At $1200 \mathrm{tU} / \mathrm{yr}$, Brazil will be mining sufficient uranium to provide for the requirements of all of Angra 1, 2, and 3; however, it will need to develop significant additional resources to produce sufficient uranium to fuel a power reactor expansion program of four to seven additional reactors.

Uranium Conversion. Brazil has no facilities for converting $\mathrm{U}_{3} \mathrm{O}_{8}$ to $\mathrm{UF}_{6}$ for enrichment; these services are currently provided by Cameco Corp. in Canada. Brazil's present conversion capabilities are at a research scale; however, a pilot plant having capacity of $40 \mathrm{tU} / \mathrm{yr}$ is under construction at the Aramar facility as part of the naval nuclear propulsion program. Although not a stated priority, Brazil does have long-term plans for construction of an industrial-scale conversion facility, possibly by 2014 (NEI 2007). 
Uranium Enrichment. Brazil has historically obtained the enrichment services required for its commercial reactors from Urenco (NEI 2007). However, Brazil is currently constructing and commissioning the Resende Enrichment Facility. The first of four modules of gas centrifuges was commissioned in May 2006 with three additional modules to be completed by 2010 for a total estimated cost of \$267 million (NEI 2007). This would result in a total enriched uranium production capacity of 20-30 t/year (NEI 2007), or 114,000 SWU/year (Defesanet 2005). This capacity is sufficient to provide about 60 percent of Angra 1 and 2 enriched uranium requirements. Two additional modules are planned to be installed by 2015 utilizing improved design centrifuges. This expansion will have sufficient capacity to provide 100 percent of Angra 1, 2, and 3 enriched uranium requirements (NEI 2007). Assuming that enrichment production required to supply 100 percent of Angra 1 and 2 needs is 203,000 SWU/yr (Defesanet 2005), the Resende plant would need to have a capacity of about 350,000 SWU/yr for Brazil to provide 100 percent of the enriched uranium requirements for Angra 1, 2, and 3. Enrichment requirements to supply Angra 1,2 and 3 and an additional seven Angra 2-type reactors would be about $1,380,000 \mathrm{SWU} / \mathrm{yr}$.

Fuel Fabrication. Brazil currently has co-located facilities to fabricate all of the nuclear fuel required for Angra 1 and 2. These facilities include: 1) a facility for conversion of enriched $\mathrm{UF}_{6}$ to $\mathrm{UO}_{2}$, having a capacity of $140 \mathrm{tU} / \mathrm{yr}$ (INB 2007a), 2) a facility for pellet fabrication, having a capacity of $120 \mathrm{tU} / \mathrm{yr}$ (INB 2007b), and 3) a facility for fuel rod and assembly fabrication, having a capacity of $250 \mathrm{tU} / \mathrm{yr}$ (INB 2007c). As shown in Table 3.1, the existing capacities of these facilities are also sufficient to supply fuel for Angra 3. A modest expansion would be required to support a power reactor expansion program of four to seven additional reactors.

\subsection{Argentina Nuclear Program}

Like Brazil, Argentina currently has two operating nuclear power reactors: 1) Atucha 1, a 335-MWe PHWR supplied by Siemens KWU that began commercial operation in 1974 and 2) Embalse, a 600-MWe PHWR (Candu 6 reactor) supplied by Atomic Energy of Canada, Ltd. (AECL) that began commercial operation in 1984. Construction on a third PHWR, Atucha 2, a 692-MWe reactor to be supplied by Siemens KWU, was initiated but never completed. The Argentine government announced in August 2006 that it would finance the completion of this plant, with operation expected in 2010 (NEI 2006). All of these reactors were originally designed to be fueled with natural uranium, although Atucha 1 has been converted to use slightly enriched uranium (SEU). Argentina is currently investigating converting both Embalse and Atucha 2 to SEU as well.

In July 2007, the Argentina and Canadian governments signed an agreement to negotiate terms of a contract by the end of April 2008 for the supply of a second CANDU 6 reactor by AECL and that includes the potential for a second reactor. The design of these reactors will be based on the twin CANDU 6 reactors in Qinshan, China, and have a generating capacity of 740 MWe each (Reuters 2007a).

Using available information on the uranium requirements for these plants, annual nuclear fuel production requirements are estimated and provided in Table 3.2 for each step in the fuel production cycle. Argentina has successfully mastered many of the steps of the fuel fabrication cycle, and has industrial-scale facilities for most of these steps. All nuclear fuel production facilities in Argentina are owned by the government. 
Summary. Table 3.2 provides a comparison of the fuel production requirements for Atucha 1 and Embalse and the existing/planned capacity of Argentina's commercial fuel production facilities. Also provided is an estimate of the fuel production requirements for planned additional nuclear power plant capacity, including the approved Atucha 2 plant and two additional Candu- 6 plants by 2020. These results reveal the following:

- Argentina currently does not produce uranium domestically, although it has in the past. Known and projected indigenous uranium resources are insufficient to provide the fuel required for current and planned reactors throughout their entire operational lives, which peaks at about $460 \mathrm{tU} / \mathrm{yr}$.

- Argentina is currently self-sufficient in uranium conversion and fuel fabrication. Existing facilities will need to be expanded to remain self-sufficient if the planned expansion of nuclear power is implemented.

Argentina's enrichment requirements are currently minimal due to their predominant use of natural uranium fuel. These requirements will increase if, as planned, Argentina converts its current and planned reactors to slightly enriched fuel. However, even conversion of all current and planned reactors to 1 percent enriched fuel would require less than 150,000 SWU/yr.

Uranium Production. Unlike Brazil, Argentina does not have significant resources of natural uranium with reasonably assured resources (RAR) of 4,880 tU recoverable at a cost of less than US\$80 per kgU (OECD 2005). Uranium has been produced intermittently on a small scale in Argentina since the 1950s. The last operational uranium mine, the Sierra Pintada mine, was shutdown in 1997 because the falling price of uranium made it uneconomical. The associated San Rafael mill (yellowcake production center), with a capacity of $120 \mathrm{tU} / \mathrm{yr}$, was placed into standby status. However, in 2005, Argentina announced that it intended to reopen the Sierra Pintada mine in 2006 and was actively investigating other uranium deposits (Goldletter 2005). However, recommissioning of the Sierra Pintada mine has been delayed due to local opposition. Table 3.2 indicates that restart of the Sierra Pintada mine would only provide about 50 percent of the uranium required to fuel Atucha 1 and 2 and Embalse. Mining capacity would need to increase by a total factor of about 4 to support the planned expansion of nuclear power.

Uranium Conversion. Argentina currently has one facility for converting $\mathrm{U}_{3} \mathrm{O}_{8}$ to $\mathrm{UO}_{2}$ and another for converting $\mathrm{UO}_{2}$ to $\mathrm{UF}_{6}$ for enrichment. The $\mathrm{UO}_{2}$ conversion facility has a capacity of $150 \mathrm{tU} / \mathrm{yr}$. Argentina is considering doubling the size of the plant to $300 \mathrm{tU} / \mathrm{yr}$ (Asteriscos 2007). This is sufficient production capacity for Atucha 1 and 2 and Embalse, but would need to be expanded further to support the two additional planned Candu- 6 reactors.

The capacity of the $\mathrm{UF}_{6}$ conversion plant is $60 \mathrm{tU} / \mathrm{yr}$, which is currently sufficient to supply the needs of Atucha 1. If Embalse and Atucha 2 are also converted to using SEU then the capacity of this plant will need to be increased. A new, industrial-scale facility would likely be required, especially if the two Candu-6 reactors are converted to use SEU.

Uranium Enrichment. Argentina operated a pilot-scale uranium enrichment plant from 1983 to 1989. The plant utilized gaseous diffusion technology and had a capacity of 20,000 SWU/yr. In 2006, Argentina announced that in 2007 it would recommission the enrichment plant utilizing the indigenously developed Sigma diffusion technology under development since 1997. From Table 3.2, the enrichment requirement for the SEU fuel used at Atucha 1 is estimated to be about 5,000 SWU/yr. If Atucha 2, Embalse, and the two additional Candu- 6 reactors were all converted to SEU fuel, enrichment requirements would be less than 150,000 SWU/yr. 
Fuel Fabrication. Argentina has a fuel element fabrication plant that has been operating since 1982. This plant, having a capacity of $150 \mathrm{tU} / \mathrm{yr}$, manufactures sintered $\mathrm{UO}_{2}$ pellets and assembles fuel elements/bundles for both the Atucha-1 (both natural and slightly enriched uranium) and Embalse nuclear power plants (NEI 2006). 
Table 3.1. Comparison of Fuel Production Requirements and Current/Planned Facility Capacity for Brazil

\begin{tabular}{|c|c|c|c|c|c|c|}
\hline \multirow[b]{2}{*}{ Fuel Production Step } & \multirow{2}{*}{$\begin{array}{l}\text { Current Production } \\
\text { Requirements } \\
\text { (Angra } 1 \text { \& 2) }\end{array}$} & \multicolumn{2}{|c|}{$\begin{array}{c}\text { Near-term Production } \\
\text { Requirements (about 2012) }\end{array}$} & \multicolumn{2}{|c|}{$\begin{array}{l}\text { Planned Production Requirements } \\
\text { (by 2025) }\end{array}$} & \multirow[b]{2}{*}{$\begin{array}{c}\text { Current/Planned Production } \\
\text { Capacity }^{\mathrm{a}}\end{array}$} \\
\hline & & Angra 3 & Total & $\begin{array}{l}\text { Angra 2-type } \\
\text { Reactors }\end{array}$ & Total & \\
\hline Mined/Milled Uranium (tU/yr) & 430 & 310 & 744 & 2,182 & 2,926 & $\begin{array}{c}340 \text { (current) } \\
640 \text { (by 2012) } \\
1,200 \text { (planned) }\end{array}$ \\
\hline $\begin{array}{l}\text { Uranium Conversion } \\
\qquad(\mathrm{tU} / \mathrm{yr})\end{array}$ & 430 & 310 & 744 & 2,182 & 2,926 & $\begin{array}{c}0 \text { (current) } \\
\text { Unknown (by 2014) }\end{array}$ \\
\hline $\begin{array}{l}\text { Uranium Enrichment } \\
\quad(\mathrm{SWU} / \mathrm{yr})^{\mathrm{b}}\end{array}$ & 203,000 & 147,000 & 350,000 & $1,030,000$ & $1,380,000$ & $\begin{array}{c}30,000 \text { (current) } \\
114,000 \text { (by 2010) } \\
350,000 \text { (minimum by } 2015)\end{array}$ \\
\hline $\begin{array}{l}\text { Enriched Uranium Powder } \\
\text { (tU/yr) }\end{array}$ & 51 & 35 & 86 & 242 & 328 & $\begin{array}{c}140 \text { (current) } \\
{[\mathrm{CF}: 36 \%]}\end{array}$ \\
\hline $\begin{array}{l}\text { Enriched Uranium Pellets } \\
\qquad(\mathrm{tU} / \mathrm{yr})\end{array}$ & 51 & 35 & 86 & 242 & 328 & $\begin{array}{c}120 \text { (current) } \\
{[\mathrm{CF}: 43 \%]}\end{array}$ \\
\hline $\begin{array}{l}\text { Enriched Uranium Fuel } \\
\text { Fabrication (tU/yr) }\end{array}$ & 51 & 35 & 86 & 242 & 328 & $\begin{array}{l}250 \text { (current) } \\
{[\mathrm{CF}: 20 \%]}\end{array}$ \\
\hline
\end{tabular}

${ }^{\mathrm{a}} \mathrm{CF}$ is short for capacity factor.

${ }^{\mathrm{b}}$ Assumes $0.3 \mathrm{wt} \%$ tails assay, $3 \mathrm{wt} \%$ enrichment for Angra- 1 , and $3.5 \mathrm{wt} \%$ enrichment for all other reactors. 
Table 3.2. Comparison of Fuel Production Requirements and Current/Planned Facility Capacity for Argentina

\begin{tabular}{|c|c|c|c|c|c|c|}
\hline \multirow[b]{2}{*}{ Fuel Production Step } & \multirow{2}{*}{$\begin{array}{l}\text { Current Production } \\
\text { Requirements } \\
\text { (Atucha } 1 \text { and } \\
\text { Embalse) }\end{array}$} & \multicolumn{2}{|c|}{$\begin{array}{c}\text { Near-term Production } \\
\text { Requirements } \\
\text { (about 2010) }\end{array}$} & \multicolumn{2}{|c|}{$\begin{array}{c}\text { Planned Production } \\
\text { Requirements (by 2020) }\end{array}$} & \multirow[b]{2}{*}{$\begin{array}{c}\text { Current/ Planned Production } \\
\text { Capacity }^{\mathrm{a}}\end{array}$} \\
\hline & & Atucha 2 & Total & $\begin{array}{l}2 \text { Additional } \\
\text { Embalse-type } \\
\text { Reactors }\end{array}$ & Total & \\
\hline Mined/Milled Uranium (tU/yr) & 160 & 100 & 260 & 210 & 470 & $\begin{array}{c}0 \text { (current) } \\
120 \text { (by 2010) }\end{array}$ \\
\hline $\begin{array}{c}\text { Uranium (yellowcake to } \mathrm{UO}_{2} \text { powder) } \\
\text { Conversion ( } \mathrm{tU} / \mathrm{yr} \text { ) }\end{array}$ & 160 & 100 & 260 & 210 & 470 & $\begin{array}{l}150 \text { (current) } \\
300 \text { (by 2015) }\end{array}$ \\
\hline $\begin{array}{c}\left.\text { Uranium ( } \mathrm{UO}_{2} \text { to } \mathrm{UF}_{6}\right) \text { Conversion } \\
(\mathrm{tU} / \mathrm{yr})\end{array}$ & 50 & 0 & 50 & 0 & 50 & $\begin{array}{l}60 \text { (current) } \\
{[\mathrm{CF}: 83 \%]}\end{array}$ \\
\hline Uranium Enrichment (SWU/yr) & 5,000 & 0 & 5,000 & 0 & 5,000 & 0 (current) \\
\hline Enriched Uranium Powder (tU/yr) & 36 & 0 & 36 & 0 & 36 & Unknown \\
\hline Natural/Enriched Uranium Pellets (tU/yr) & 131 & 89 & 220 & 190 & 410 & $\begin{array}{l}150 \text { (current) } \\
{[\mathrm{CF}: 87 \%]}\end{array}$ \\
\hline Natural/Enriched Fuel Fabrication (tU/yr) & 131 & 89 & 220 & 190 & 410 & $\begin{array}{l}150 \text { (current) } \\
{[\text { CF: } 87 \%]}\end{array}$ \\
\hline
\end{tabular}

${ }^{\mathrm{a}} \mathrm{CF}$ is short for capacity factor. 



\subsection{Energy Resource Endowments and Constraints}

Brazil and Argentina currently have significant demands to increase their electricity generating capacity. It is projected that Brazil will need an additional $98 \mathrm{GW}$ by 2030 , more than a 100 percent increase in current capacity. Forecasts for Argentina's energy consumption independent of Latin America were not available. However, given Argentina's per capita income is significantly higher than Brazil's, and its electricity consumption is similar to Brazil's at about $2000 \mathrm{kWh}$ per capita, ${ }^{8}$ similar growth rates would be expected. The European Commission (2003) and EIA (2007) forecast Latin America's electricity consumption to double by 2030. Given that populations are expected to grow 3 percent annually in Latin America (European Commission 2003), 3.5 to 4.0 percent annual growth in generation will not provide sufficient growth in supply to match growth in consumption.

The investment required to build Brazil's capacity is estimated to be US\$254 billion, half of which would be used for transmission and distribution capacity. The two countries have significant untapped energy resources, especially in hydroelectricity generation. However, because of significant variability in annual rainfall and significant public opposition to increased hydropower capacity, hydropower may not provide the reliable source of electricity needed for baseload production. Brazil also has significant coal resources; however, they are of low quality and so it is cheaper to import higher quality coal. Brazil has the potential to develop its oil reserves, which are significant, but any increases in this production would likely be diverted to meet future transportation needs. Given the issue of climate change, nuclear and hydropower appear to be the most viable resources to tap to meet future electrical energy needs.

\subsection{Brazil}

\subsubsection{Projected Electricity Generation in Brazil}

Brazil's electricity generating capacity was $87 \mathrm{GW}$ in 2004 . These plants generated $386.9 \mathrm{TWh}$ of electricity, over 80 percent of which was produced by large hydropower plants (see Figure 4.1). The contribution of nuclear energy to this production was just 3 percent (Angra 1 and 2). Electricity generation is projected to increase to 731.2 TWh by 2030 , requiring the addition of $98 \mathrm{GW}$ of new generating capacity (IEA 2006). The IEA projection assumes that most of the increase in generation capacity is provided by new large hydropower plants, with additional nuclear generation capacity being provided by the completion of Angra 3 and (potentially) one additional $1.3 \mathrm{GWe}$ plant.

\subsubsection{Potential Issues with Expanding Generating Capacity}

The investment required to build additional electricity generating and distribution capacity is estimated to be US $\$ 254$ billion (IEA 2006). Issues surrounding Brazil's ability to provide new electricity generating capacity include:

\footnotetext{
${ }^{8}$ Electricity consumption per capita in Argentina and Brazil is about $1 / 6$ of the U.S.'s per capita consumption.
} 
- Hydropower - Brazil has significant undeveloped hydropower resources. However, as mentioned previously, the construction of large hydroelectric dams has become a major environmental issue in Brazil. The inability to construct additional hydroelectric capacity on a reasonable schedule is held out by the government as one reason for the possible accelerated expansion of nuclear power.

- Coal - While Brazil has significant coal reserves, these reserves generally have high ash and sulfur content and low caloric values. Consequently, it is cheaper to import coal (mostly from United States and Australia) than to produce it domestically.

- Natural Gas - Brazil also has significant natural gas resources. However, inadequate transport infrastructure has been an obstacle to developing these resources necessitating significant import of natural gas from Bolivia.

- Oil - Brazil is the $15^{\text {th }}$ largest oil producer in the world with significant undeveloped reserves. Brazil is self-sufficient in oil production, but has insufficient refining capacity to meet domestic consumption needs (additional refining capacity is currently under construction). Future increases in production are expected to be principally utilized to meet transportation sector needs.

- Distribution Infrastructure - Transmission and distribution losses in Brazil are among the highest in the world (17 percent of total domestic supply). Losses are high because of the long distances over which power is transmitted, old and poorly maintained transmission and distribution systems, and power theft. Half of the investment required in electricity generating and distribution capacity by 2030 , or US\$127 billion, is for additional transmission and distribution capacity.
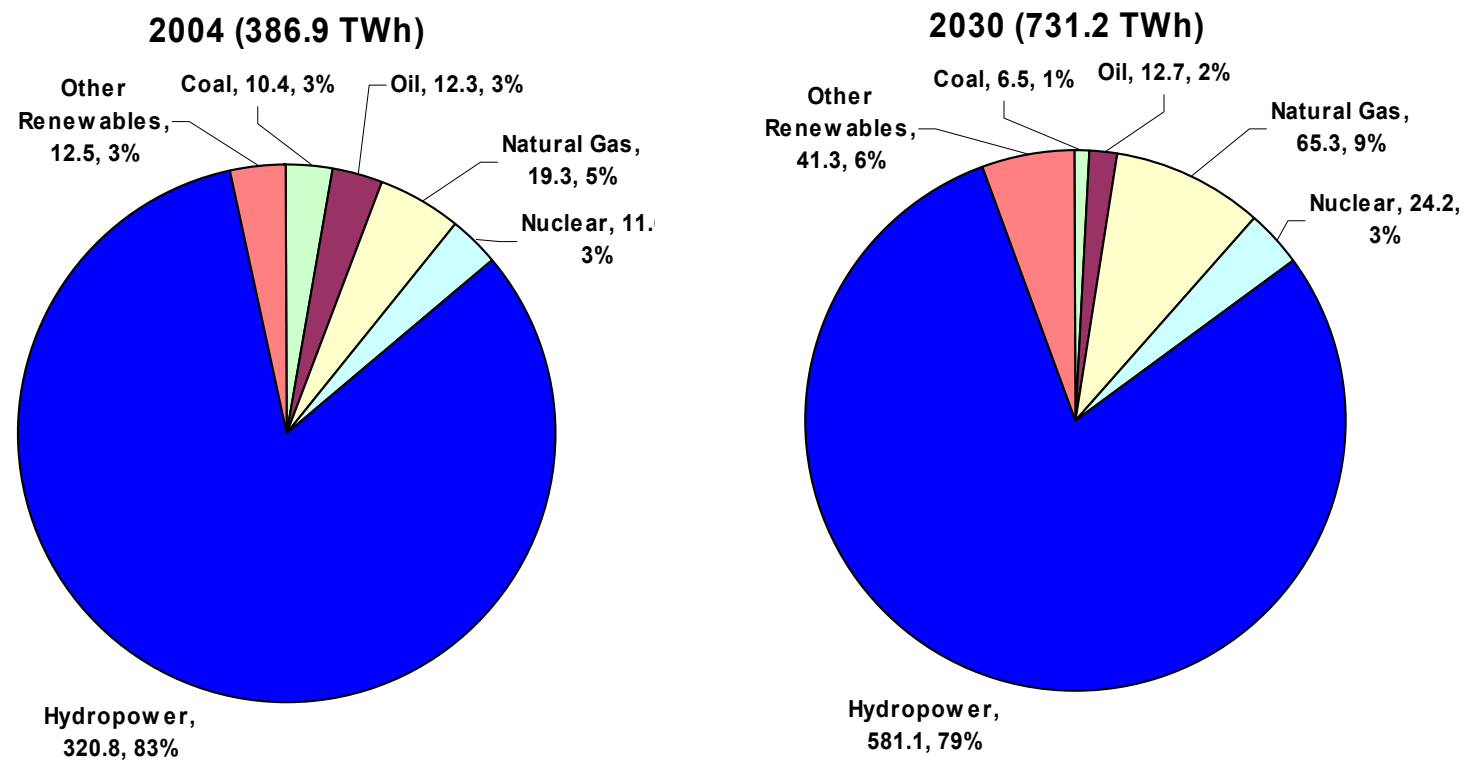

Figure 4.1. Current and Projected Electricity Generation in Brazil 


\subsection{Argentina}

\subsubsection{Projected Electricity Generation in Argentina}

Argentina's electricity generating capacity was $24 \mathrm{GW}$ in 2006. Total electricity generation was 100.3 TWh in 2004, 60 percent of which was produced by conventional thermal plants (mostly natural gas) and 30 percent was produced by hydropower plants (see Figure 4.2) (IEA 2008). Nuclear's share of this production was just 8 percent (Atucha 1 and Embalse). Electricity generation increased at a rate of 5.4 percent per year between 1999 and 2004, which equates to additional electricity generation capacity of about $600 \mathrm{MWe} / \mathrm{year}$. This increased production was almost all from additional gas-fired power plants.

\subsubsection{Potential Issues with Expanding Generating Capacity}

Issues surrounding Argentina's ability to provide new electricity generating capacity include:

- Hydropower - Argentina has significant undeveloped hydropower resources. In 2004, 30,000 GWh were produced, representing about 25 percent of the estimated technically feasible resources available. However, as with Brazil and elsewhere, significant opposition has developed to further development of hydropower in Argentina. The World Energy Council (WEC) Member Committee reports that there were no hydro plants under construction in Argentina at the end of 2005, but that some 2,400 MWe of new capacity is planned. The bulk of this additional capacity is from Argentina's 50 percent share in two bi-national plants: one with Brazil and the other with Paraguay (World Energy Council 2007).

- Coal - Argentina has very limited coal resources and most of that which it does have is lignite, which has high ash content and a low caloric value. Consequently, most of what little coal that is used in Argentina is imported.

- Natural Gas - Argentina has the $3^{\text {rd }}$ largest proven reserves of natural gas in Latin America, behind Venezuela and Mexico. Argentina is also the largest net producer of natural gas in Latin America, and the most efficient with little production lost due to flaring and shrinkage and minimal reinjection. Argentina uses most of its natural gas production for indigenous electric power production, but also exports to various countries, primarily Chile. However, existing production capacity is not sufficient to meet exceptional demand (e.g., hot summers, cold winters, or low-water levels). During such times, Argentina will suspend exports, which has severely strained Argentina's relations with Chile (The Economist 2007).

- Oil - Argentina has a modest endowment of crude oil, is self-sufficient in oil production, and exported about 25 percent of its production in 2004. Privatization of the oil sector in the 1990s dramatically increased oil production.

- Distribution Infrastructure - Transmission and distribution ownership is open to private industry, although heavily regulated. Like most of Latin America, transmission and distribution losses in Argentina are high. Losses in 2005 were 13.6 percent of total domestic supply (World Bank 2008). 


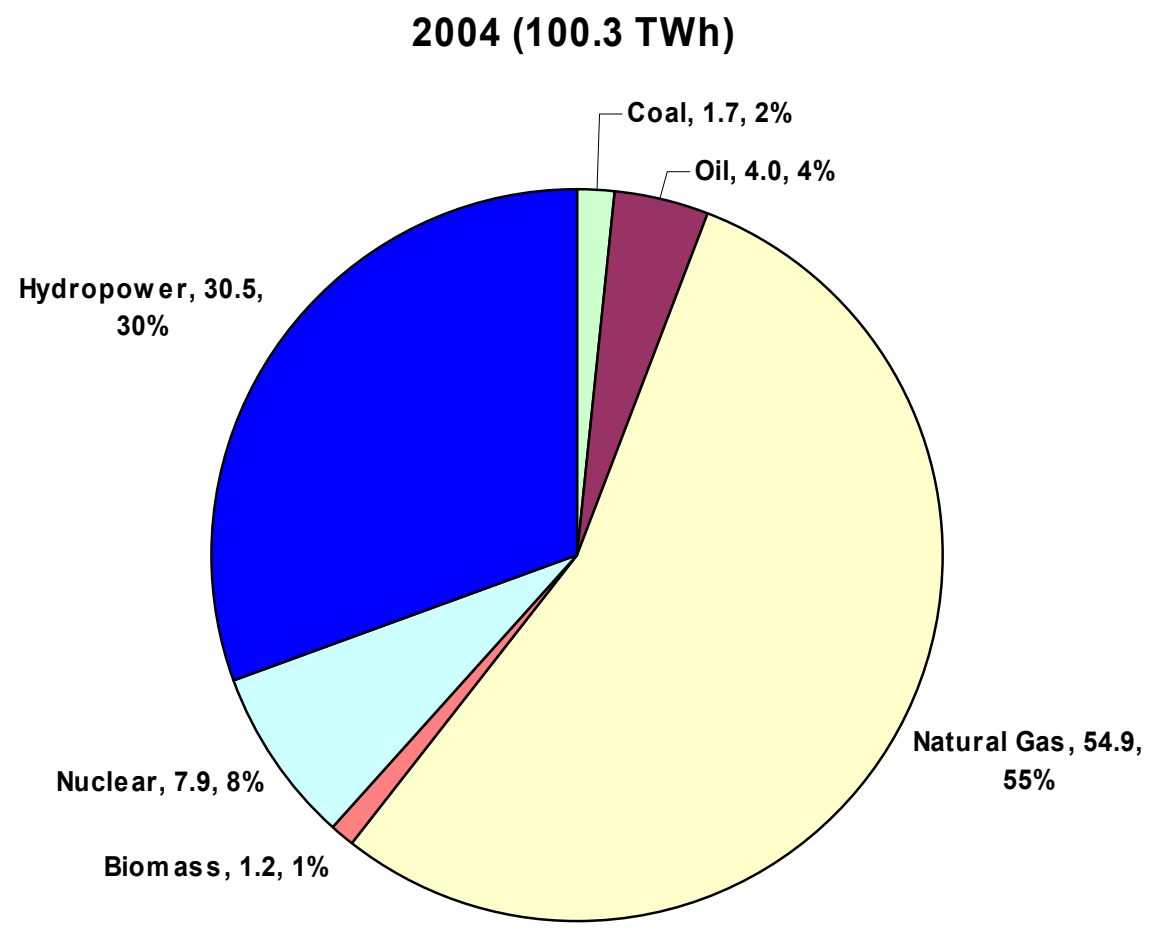

Figure 4.2. Current Electricity Generation in Argentina 


\subsection{Current Costs for Enrichment Services}

Brazil's near-term enrichment efforts will not be cost-competitive in the world market. The current plan for a 114,000 SWU per year plant is substantially smaller than the 3 million SWU per year capacity that is associated with the cost competitive facilities of Urenco and Areva. The costs for the 114,000 SWU per year capacity Resende plant are estimated at $\$ 163$ per SWU (Table 5.1). However, the initial plant is only being built to meet 60 percent of the current needs for the Angra 1 and 2 nuclear power plants. If Brazil expands the current facility to meet the needs of Angra 1, 2 and 3, the levelized average total costs of adding the additional capacity would be approximately $\$ 125$ per SWU; while not competitive with larger facilities, costs could be competitive at current SWU prices in the spot market should Brazil be able to scale the plant.

Building a plant large enough to provide all of the enrichment services for the current and proposed additional seven nuclear plants (about 1.4 million SWU total) could drop average costs of adding the additional capacity to approximately $\$ 80$ per SWU (2006 constant\$). Expanding the capacity of the Resende facility to 3 million SWU per year would result in unit SWU production costs similar those of current plants being built by Areva and Urenco should they be able to successfully scale their current design. Modern gas centrifuge technology (such as used by Urenco) can produce SWU at an average cost of about \$60-70 per SWU (2006 constant\$) (Rothwell and Braun 2008).

\subsection{Cost Comparisons for Established Enrichment Facilities}

Cost estimates for enrichment services range from $\$ 31 / \mathrm{SWU}$ to $\$ 135 / \mathrm{SWU}$ (2006\$) for current market producers. Existing depreciated facilities set the lower end of the range. Rothwell and Braun (2008) estimated the Tenex/Russian plants between $\$ 22$ and \$48/SWU (2006\$) using only repairs, labor and electricity costs. The gaseous diffusion plants in the United States and France set the upper end of the range. The United States Enrichment Corporation (USEC) American Centrifuge Plant (ACP) is less efficient than the Eurodif plant using 2,500 kWh per SWU compared with 2,200 kWh per SWU. If electricity is $\$ 45 / \mathrm{MWh}$, then Eurodif plant costs are $\$ 13.5 / \mathrm{SWU}$ less expensive at $\$ 119.5 / \mathrm{SWU}$. The Urenco National Enrichment Facility (NEF), located in the United States, was estimated at $\$ 57 / \mathrm{SWU}$ in 2006\$ (Rothwell and Braun 2008). The spot market for SWU, which gives an estimate for future market prices, was $\$ 143 /$ SWU at the end of January 2008 (UxC 2008).

\subsection{Costs of the Current Facility and Future Expansion of Resende Plant}

We estimated the costs of the Resende plant based on information in Rothwell and Braun (2008). The current plant came on line in 2006 with only about 4,000 SWU capacity (essentially a pilot plant) (Terça-feira 2006.). The initial 4,000 SWU cost approximately $\$ 300$ million Brazilian Reals ${ }^{9}$ (BR $\$$ ), while Industrias Nucleares do Brasil (INB) expects to spend BR $\$ 250$ million more completing the facility (Defesanet 2005; Jornal da Ciencia 2006).

\footnotetext{
${ }^{9}$ Plural for Real, the Brazilian currency.
} 
Using equations derived by Rothwell and Braun, we scaled the costs to obtain levelized costs for the enrichment costs of the Resende facility. We estimated costs based on the cost of the 114,000 SWU per year plant; expanding to a 350,000 SWU per year plant (the size needed to supply Angra 1, 2, and 3); expanding to meet current and future requirements of 1.4 million SWU per year (the size needed to supply Angra 1, 2, and 3 and seven additional reactors); and outright building an Areva-sized 3 million SWU per year plant. Capital was scaled using a four-year construction period to include interest during construction, a 10 percent contingency was added and capital was assumed borrowed at the real rate of interest in Brazil (6.75 percent). The facility was assumed to have a 30 year life. Labor costs were also scaled. The number of laborers was directly calculated using the Rothwell and Braun (2008) equations and the labor was based on the average INB labor rate (2006). Salaries were inflated to BR \$2006 using the International Monetary Fund inflation for Brazil. Salaries were weighted burden by a 70 percent burden rate. Electricity costs were based on the plant consuming about $110 \mathrm{kWh} / \mathrm{SWU}$. We used 9.2 cents per kWh as in Rothwell and Braun (2008). Material costs were estimated at 1 percent of capital including IDC and contingency. The values obtained are shown in Table 5.1. The table indicates that because the SWU cost is significantly impacted by the size of the facility and additional units can be added at significantly less cost than the first module, one could expect Brazil's enrichment costs to approach similar costs to Urenco and LES if they decided to compete in the world market.

Table 5.1. Estimated Costs of Brazilian Enrichment Different-Size Plants (2006\$)

\begin{tabular}{lcccrc}
\hline Plant Size SWU (000) & 114 & 350 & 1,266 & 3,000 \\
\hline Capital Cost & $\$ 103.39$ & $\$ 84.12$ & $\$ 53.45$ & $\$ 42.34$ \\
Labor Cost & $\$ 36.93$ & $\$ 20.15$ & $\$ 10.06$ & $\$ 6.32$ \\
Electricity Cost & $\$ 10.12$ & $\$ 10.12$ & $\$ 10.12$ & $\$ 10.12$ \\
Repairs \& Maintenance & $\$ 13.16$ & $\$ 10.71$ & $\$ 6.80$ & $\$ 5.39$ \\
\multicolumn{1}{c}{ Total Cost/SWU } & $\$ 163.60$ & $\$ 125.10$ & $\$ 80.44$ & $\$ 64.17$ \\
\hline
\end{tabular}

\subsection{Delineation of Argentina Costs for Development of Enrichment Services}

Argentina is poised to re-commission a pilot-scale gaseous diffusion enrichment plant utilizing the indigenously developed Sigma diffusion technology. They claim the costs per SWU will be in the \$50US $\$ 70 /$ SWU range. The redeveloped plant is estimated to have a 500,000 SWU per year capacity (Jinchuk 2005), relatively small in comparison to the 3-7.5 million SWU per year capacities for Urenco. Argentina's stated purpose for restarting the enrichment facility was to maintain its rights to operating enrichment services (UIC 2007a, NTI 2007). The Argentine claims would not appear to be attainable given current costs and technological restrictions associated with gaseous diffusion enrichment 


\subsection{Demand and Supply of Enrichment Services}

Currently, world enrichment services closely match enrichment service demand. However, the current United States-Russia HEU agreement and the suspension agreements keep some Russian SWU from entering the market. Thus, spot prices for enrichment services currently exceed $\$ 140$ per SWU, which is somewhat above long-term costs. As Russia has indicated it does not plan to extend the United States-Russia HEU agreement, it is possible that this SWU will become available.

\subsection{Brazil}

\subsubsection{National LEU Quantities to Meet Domestic Requirements}

Brazil's demand for enrichment services and LEU could grow significantly if their vision for a significantly larger peaceful civilian nuclear energy program is realized. With a demand for 1,380,000 SWU per year, a Brazilian enrichment facility would be large enough to capture most of the economies of scale associated with large enrichment facilities. According to Rothwell and Braun (2008), a significant portion of the economies of scale can be captured by reaching the $1,380,000$ SWU per year output level.

Brazil's proposed fleet of PWRs would require approximately 330 tU/year to meet its fuel requirements. Brazil's current capacity would need to be expanded significantly in powder (140 tU/year currently) and pellet (120 tU/year currently) manufacturing, while fabrication ( $250 \mathrm{tU} / \mathrm{year}$ currently) only needs to increase by one-third.

The significant issue for Brazil is obtaining the capital required for the expansion. With an additional \$3.7 billion required to complete the Angra 3 unit (BBC News 2007), and assuming US\$4-\$5 billion each for the additional seven Angra 2-style PWR reactors, nearly \$28-\$35 billion would be required just to build the reactor facilities. The new reactor costs are based on an Annual Energy Outlook (EIA 2008) estimate of $\$ 4-5$ billion per 1000-MW reactor; with the $\$ 5$ billion being today and the $\$ 4$ billion being in 2030.

Assuming about $\$ 1$ billion (Cabrera-Palmer and Rothwell 2008) is required to build a 1.5-million SWU per year enrichment facility, the total cost, including nuclear reactor costs, comes to a range of \$33$\$ 40$ billion in ca 2006 constant\$. Given that Brazil's tax revenues ( $\$ 244$ billion) are expected to exceed outlays ( $\$ 219$ billion) in 2007 (CIA 2008), such an expenditure by the government would seem within its capability if distributed over the period of construction (through 2025).

\subsection{Argentina}

\subsubsection{National LEU Quantities to Meet Domestic Requirements}

Argentina's nuclear power sector is significantly smaller than Brazil's and its future expansion is expected to be built on CANDU technology using slightly enriched uranium. Argentina plans to recommission enrichment services to provide 500,000 SWU per year of slightly enriched uranium for its proposed expansion of nuclear power reactors. Demand for slightly enriched uranium only calls for 
5,000 SWU per year and 410 tU/year uranium to meet Argentina's proposed $\$ 3.5$ billion expansion of the nuclear power industry (assuming Embalse and the new reactors are fueled with natural uranium).

Argentina currently gets its enrichment services from the United States.

\subsection{Regional Demand for Enrichment Services}

The Energy Information Agency (EIA 2007) expects nuclear power demand to grow at a 1.8 percent annual rate in Latin America (Brazil excluded). With the exception of Mexico, there is no nuclear power production in Latin America outside of Brazil and Argentina. Mexico expects to increase output to 1,500 MWe by 2010. Because of the dependence on natural gas and renewable energy sources such as hydropower, there is some discussion of bringing nuclear power to Chile, and Peru. Droughts significantly affect the output from hydroelectric plants over time, driving the need for more dependable supplies. High natural gas prices have also driven some governments to begin studying the nuclear power option.

Currently Mexico is the only other Latin American country with nuclear power, and therefore a demand for nuclear fuel. The two Laguna Verde plants use BWRs with a rated output at $680 \mathrm{MW}$ each. Mexico currently obtains its uranium supplies as $\mathrm{UF}_{6}$ from Comurhex in France. Enrichment services are provided by the U.S. Department of Energy and fabrication services are provided by General Electric in the United States (NEA 2007). Mexico is expected to upgrade its Laguna Verde plants to a 1,500 MW rated capacity by 2010 (Reuters 2007b).

Venezuela would like to partner with Brazil and Argentina to develop a nuclear program in that country (Rohter and Forero 2005). Chile is also looking to expand nuclear power production (PTO 2006). However, no decision to move forward with nuclear power is expected until at least 2010 because the current government opposes nuclear power (Long 2007). The pressure will begin to mount to develop alternative energy sources as petroleum prices rise and gas shortages continue (Turner 2008). Nuclear power may be one of the alternatives

\subsection{World Demand for Enrichment Services}

Globally, demand for electricity is expected to increase 2.4 percent annually through 2030 to more than $30 \mathrm{TWh}$. Despite the overall increase in electricity output, nuclear power is expected to grow only 1.3 percent globally, accounting for 3.6 TWh, up from 2.6 TWh (EIA 2007). The 38 percent growth in nuclear power output would call for a 38 percent growth in enrichment services, ceteris paribus.

Current restrictions on the purchase of Russian SWU have driven current spot prices up to $\$ 143$ per SWU (UxC 2008) given that USEC is theoretically setting the market at $\$ 133 /$ SWU. Thus with Russian SWU unable to currently enter the market, tight market conditions have driven the price to its current position. In addition, questions about the timeframe for capacity coming online are also driving the market. However, the current tightness in the overall market cannot be translated to an overall tightness in the long-run supply of SWUs (NAC International 2007). According to Table 6.1, supplies of SWU are projected to increase by more than 27 percent from 2006 to 2015 while demand is expected to increase by 17 to 30 percent. Depending on the forecast, projected capacity could be overbuilt or underbuilt. If capacity is overbuilt, the long-run price will not be adequate to build new facilities and perform capital recovery on all facilities. A perpetual shortness in capacity could ensure that new facilities more than recover their costs. 
Table 6.1. Current Suppliers and Market Share, Projected Market Share (UIC 2007b)

\begin{tabular}{|c|c|c|c|c|c|c|}
\hline & 2002 & & 2006 & & 2015 & \\
\hline Company/Country & MTSWU & Share $(\%)$ & MTSWU & Share $(\%)$ & MTSWU & Share $(\%)$ \\
\hline AREVA/France & $10,800^{*}$ & 23.5 & $10,800^{*}$ & 22.3 & 7,500 & 12.1 \\
\hline $\begin{array}{l}\text { Urenco/Netherlands, UK, } \\
\text { Germany }\end{array}$ & 5,800 & 12.6 & 9,000 & 18.6 & $11,000+$ & 17.8 \\
\hline JNFL/Japan & 900 & 2.0 & 1,050 & 2.2 & 1,500 & 2.4 \\
\hline USEC/United States & $8,000^{*}$ & 17.4 & $11,300^{*(a)}$ & 23.3 & $3,500+$ & 5.7 \\
\hline Urenco \& AREVA/United States & 0 & 0.0 & 0 & 0.0 & $4,000+$ & 6.5 \\
\hline Tenex/Russia & 20,000 & 43.5 & 25,000 & 51.6 & $33,000+$ & 53.4 \\
\hline CNNC/China & 1,000 & 2.2 & 1,000 & 2.1 & $1,000+$ & 1.6 \\
\hline Other & 5 & 0.0 & 300 & 0.6 & 300 & 0.5 \\
\hline Total & 46,000 & & 48,450 & & 61,800 & \\
\hline Requirements & $<>$ & & 48,428 & & $\begin{array}{l}57,000- \\
63,000\end{array}$ & \\
\hline
\end{tabular}

*Plants using gaseous diffusion technology.

(a) The increase in U.S. SWU capacity is reflective of sales of down-blended HEU, not an increase in capacity.

\subsection{Brazilian Economy}

Economy. The Brazilian Gross Domestic Product (GDP) has grown 3 to 5 percent per year since 2004 and the International Monetary Fund projects that the Brazilian economy will continue growing in the same range through 2013. Stable growth provides the government with the potential to invest in its nuclear program should it decide to do so. As the government no longer holds any foreign denominated debt, it no longer is at exchange rate risk as it was in the late 1990s. ${ }^{10}$ The debt, however, does appear to be inflation indexed so Brazil does need to keep its economy in a stable position in order to continue utilizing international money markets.

Brazil's requirement to obtain over $\$ 250$ billion in financing for electricity generation and infrastructure to meet its economy's demands by 2030 would require more than $\$ 12$ billion a year-over half of the budget surplus of $\$ 25$ billion reported by the CIA (2008) for calendar year 2007. Net revenue is approximately 22 percent of GDP. Should the Brazilian economy sustain a 4 percent growth rate from now until 2030, their total GDP will more than double, growing from $\$ 1.3$ trillion in 2007 to 3.2 trillion in 2030 (in real terms). Given no major currency exchange rate issues and steady growth, Brazil could meet its needs.

\footnotetext{
${ }^{10}$ When Brazil was faced with a staggering U.S. dollar-denominated debt due to a devaluing Brazilian currency.
} 
Exchange Rate Issues. Since 2006, the Brazilian Real has appreciated 28 percent against the U.S. dollar. If the appreciation is transitory, then Brazilian SWU costs for a 3 million SWU per year facility could be competitive if Brazil should decide to build such a plant and it succeeds in scaling its current design at our cost projection estimates. During the same period the Real has only increased 5 percent against the Euro, indicating that Brazilian SWU costs could remain competitive in the world market. 


\subsection{Policy Options}

The U.S. government has several policy options available to respond to the on-going development of uranium enrichment capability and facilities in Brazil and Argentina. These options include 1) imposing economic sanctions and/or export controls to prevent or delay access to technology and technical knowhow, 2) offering reliable fuel services and supply (RFS\&S) arrangements that incentivize these countries to end further development of enrichment capability, and 3) working with the international community to develop and implement advanced safeguards methods and technology for existing and future enrichment plants. The implications of each of these policy options are assessed in this section, and recommendations for the U.S. government's path forward are proposed.

\subsection{Economic Sanctions and Technology Denial}

Economic sanctions, specifically unilateral and/or multi-lateral trade restrictions, have historically been the tool-of-choice to coerce national governments to change against their will. Technology denial or export controls, in particular, have been used to limit the spread and use of sensitive nuclear technologies. While this approach has been effective at impeding such projects where imported components or materials are required, it has failed to prevent countries from pursuing wholly indigenous projects. Brazil's and Argentina's enrichment projects are examples. Both countries initiated uranium enrichment development projects in response to restrictions on the transfer of nuclear technology that were imposed by nuclear suppliers following the India nuclear bomb test in 1974.

Nevertheless, a multi-lateral technology denial strategy could be effective. Both countries have ambitions/plans to further expand the use of nuclear power. However, neither country currently has the capability to indigenously design or construct a nuclear power plant; critical nuclear reactor components and engineering expertise must still be imported. A technology denial strategy involving multiple suppliers could be devised to deny access to critical nuclear reactor technology. Specifically, the capability to fabricate ultra-large forgings for LWR pressure vessels currently resides only with Japan (Japan Steel Works, Ltd.) and Russia (OMZ), although China could export smaller LWRs (China has exported small LWRs to Pakistan). However, because of the bottleneck created by the existence of only one western supplier of ultra-large forgings and increasing demand for these forgings, it is expected that additional suppliers of ultra-large forgings will materialize in the next few years. For example, China (China First Heavy Industries Company Ltd.), England (Sheffield Forgemasters International Ltd.), South Korea (Doosan Heavy Industries \& Construction Co.), and Japan (Casting \& Forgings Corp.) have all indicated that they are investing to provide these ultra-large forgings in the next few years (thestar.com 2008). Furthermore, PHWR technology, which doesn't require ultra-large forgings, is currently only exported by Canada. India could also export smaller PHWRs, although it has not done so to date.

However, imposition of limited multi-lateral or unilateral export controls would likely back-fire. It is easy to speculate that an export control regime that does not include China, for example, could result in a bilateral agreement in which China provides power reactor technology in exchange for Brazilian uranium. In fact, Brazil has already held discussions with China on exporting surplus uranium, preferably enriched uranium, to China. While the Brazilian constitution would need to be amended to permit such a bilateral agreement since it currently bans the export of nuclear materials, the imposition of sanctions could be a motivating force for an expedited amendment. 
If a multilateral agreement were to be reached on restricting the export of nuclear power reactor technologies to Brazil and Argentina, the effect would be to significantly impede (delay), but not prevent, expansion of nuclear power use in Argentina and Brazil. Over the next 10 to 20 years, both countries could choose to expend significant resources (billions of dollars) to acquire indigenous nuclear power reactor capability. Delaying installation of new nuclear power plants would limit enrichment requirements to what would be needed by existing plants over the next 20 to 30 years, significantly reducing the economic justification for Resende. Brazilian marginal costs for a 350,000 SWU/year plant are estimated to be approximately $\$ 125$ per SWU, which is about 60 percent higher than the estimated cost of enriched uranium to be produced by the 3 million SWU/year URENCO LEF plant currently under construction in the United States (estimated to be approximately $\$ 75$ per SWU)). The $\$ 125$ per SWU marginal cost of the Resende plant is somewhat less than the current spot market price of $\$ 143$ per SWU. Thus, if selling enrichment at current spot prices, Brazil could earn approximately $\$ 18$ per SWU, which would help recover sunk costs associated with the early development. However, the average cost of the Resende plant that would yield complete recovery of sunk costs is estimated to be $\$ 152$ per SWU. Therefore, Brazil would effectively be providing a subsidy of about $\$ 10$ per SWU if they were to sell their enrichment services at the current spot market price of \$143 per SWU

The use of sanctions could have significant ramifications for the broader U.S. policy objectives stated under GNEP, particularly for the RFS\&S initiative, which could be severely, even fatally, damaged. The use of sanctions would reinforce to the world that the current nuclear technology suppliers are unreliable and further embolden states to pursue wholly indigenous nuclear capabilities, including uranium enrichment.

\subsection{Reliable Fuel Services and Supply}

While economic sanctions have historically been the tool-of-choice to coerce national governments to change policy, more recent initiatives focus on providing incentives. Incentive packages try to provide "an attractive offer" to encourage countries not to pursue proliferation-sensitive technology development programs. The U.S. fuel bank initiative, ${ }^{11}$ for example, could provide assurance of nuclear fuel services and supply in exchange for a country agreeing to not pursue indigenous enrichment and reprocessing programs. However, the availability of the emergency fuel bank would not seem to be sufficient to convince Brazil to give up its enrichment program. Brazil has already made significant investments in developing enrichment technology and has started construction and commissioning of an enrichment plant. Additionally, Brazil's anticipated enrichment needs (including commercial nuclear power and indigenous supply of HEU for naval reactors), which could not easily be provided for under nuclear trade arrangements, offer economic justification for its enrichment program.

It is possible that a broader initiative package, including "take-back" of spent nuclear fuel (SNF) provided by a RFS\&S backend regime and/or providing for shares in an international enrichment center, could provide sufficient incentive for Brazil/Argentina to give up their enrichment programs. Each of these options is discussed in turn.

\footnotetext{
${ }^{11}$ The U.S. government has made available 17.4 MT of HEU that is being down-blended to LEU for use as an emergency fuel bank against market supply disruptions.
} 


\subsubsection{SNF Take-Back}

There are tremendous political issues associated with an SNF take-back offer, ${ }^{12}$ and in order to establish the seriousness of the U.S. government, Brazil/Argentina could demand early demonstration of U.S. government commitment by requiring early removal of SNF from their countries. The RFS\&S scenario considered here evaluates the cost of returning SNF from Brazil/Argentina to the United States beginning in 2010 and continuing through 2030 and that has been discharged from the reactor at least 5 or 10 years.

The cost of the RFS\&S scenario evaluated here assumes 1) direct disposal in a geologic repository, 2) dry storage for 40 years prior to geologic disposal, 3) land transport from the U.S. receiving port to the dry storage/final disposal site, and 4) sea transport from Brazil to the United States. The total overnight cost, not accounting for discounting or escalation, of disposition of SNF through 2030 is estimated to range from $\$ 0.5$ billion to $\$ 1.8$ billion for Brazil. A breakdown of this cost estimate is provided in Table 7.1. This analysis assumes that the unit cost factors available for U.S. SNF are applicable to Brazilian SNF since the SNF from the Brazilian PWR-type plants have characteristics (e.g., physical dimensions, burnup, heat generation) similar to that of U.S. SNF.

However, SNF from the Argentine PHWR-type plants have vastly different characteristics than U.S. SNF and so the unit cost factors for U.S.-used fuel are not applicable to Argentine SNF. Development of unit cost factors for PHWR-type SNF is beyond the scope of this analysis and so a cost estimate was not developed for take-back of Argentine SNF. However, projected Argentine SNF inventories based on operation of Atucha 1 and Embalse in 2010, startup of Atucha 2 in 2011, and startup of two additional Embalse-type plants in 2016 and 2021 are as follows:

- Take-back in 2010, time since discharge of 5 years -2,960 $\mathrm{kgHM}$

- Take-back in 2010, time since discharge of 10 years -2,480 kgHM

- Take-back in 2030, time since discharge of 5 years $-7,840 \mathrm{kgHM}$

- Take-back in 2030, time since discharge of 10 years - 5,950 kgHM

\subsubsection{Regional Enrichment Center}

An RFS\&S alternative to SNF take-back might be to seek to split off Argentina from Brazil by making an offer for a technology limited partnership in a U.S.-hosted international enrichment consortium. ${ }^{13}$ Assuming Brazil has naval and nationalist interests, it would most likely turn down such an offer. However, with fewer resources, Argentina might consider such a partnership, particularly if they received guaranteed shares of the plant output. This would provide a near-term revenue stream to Argentina, as well as assurance of supply. Furthermore, if Argentina used its production share to supply the small amount of SWU its reactors need and other South/Latin American reactors (sans Brazil) at an

\footnotetext{
${ }^{12}$ It is highly unlikely that the United States could feasibly offer near-term take-back of SNF to U.S. soil, and no other country has yet been found to host a facility for long-term storage of SNF.

${ }^{13} \mathrm{An}$ example is the recently completed deal in which Suez (which owns Electrabel, the operator of two nuclear power plants in Belgium) purchased a 5 percent stake in the Georges Besse II enrichment plant currently under construction in France. With this investment, Suez is "able to secure a portion of its nuclear reactor supply needs in enriched uranium" (WNN 2008).
} 
internationally competitive cost of $\$ 76 / \mathrm{SWU}$, then it might become the defacto regional enrichment supplier. Once Brazil gives up on a nuclear navy (likely), and realizes its small enrichment plant producing at a cost of $\$ 125 / \mathrm{SWU}$ can't compete on cost, it might come around and buy a share in the international enrichment consortium itself (and close the Resende enrichment plant).

Table 7.1. Estimated Cost for Take-Back of Brazilian SNF

\begin{tabular}{|c|c|c|c|c|c|c|c|c|c|c|c|c|}
\hline \multirow{3}{*}{$\begin{array}{c}\text { Take- } \\
\text { Back } \\
\text { Time } \\
\text { Period }\end{array}$} & \multirow{3}{*}{$\begin{array}{c}\text { Time } \\
\text { Since } \\
\text { Discharg } \\
\text { e } \\
\text { (yrs) }\end{array}$} & \multirow{3}{*}{$\begin{array}{c}\text { SNF } \\
\text { Quantity } \\
1 \\
\text { (kgHM) }\end{array}$} & \multicolumn{10}{|c|}{ Cost $(2006 \$ M)$} \\
\hline & & & \multicolumn{2}{|c|}{$\begin{array}{c}\text { Direct } \\
\text { Disposal2 }\end{array}$} & \multicolumn{2}{|c|}{ Dry Storage3 } & \multicolumn{2}{|c|}{$\begin{array}{c}\text { Land } \\
\text { Transportation4 }\end{array}$} & \multicolumn{2}{|c|}{$\begin{array}{c}\text { Sea } \\
\text { Transportation5 }\end{array}$} & \multicolumn{2}{|c|}{ Total } \\
\hline & & & Low & High & Low & High & Low & High & Low & High & Low & High \\
\hline \multirow{2}{*}{2010} & 5 & 240 & 91 & 183 & 24 & 204 & 16 & 25 & 36 & 72 & 168 & 483 \\
\hline & 10 & 160 & 61 & 122 & 16 & 196 & 11 & 16 & 24 & 48 & 112 & 383 \\
\hline \multirow{2}{*}{2030} & 5 & 1250 & 478 & 958 & 125 & 295 & 86 & 128 & 188 & 376 & 877 & 1,757 \\
\hline & 10 & 740 & 283 & 568 & 74 & 249 & 51 & 76 & 112 & 223 & 520 & 1,117 \\
\hline
\end{tabular}

${ }^{1}$ SNF Quantity. SNF inventory through 2010, taken from DOE, 2001, is based on operation of Angra 1 and 2. SNF projection to 2030 assumes Angra 3 startup in 2011 and startup of 7 additional Angra 3 type plants in 2016, 2020, 2021, 2022, 2023, 2024, and 2025.

${ }^{2}$ Direct Disposal. Low cost assumes a 270,000 MTHM repository maximum capacity ( $\left.\$ 381 / \mathrm{kgHM}\right)$; high cost assumes a 70,000 MTHM repository maximum capacity $(\$ 764 / \mathrm{kgHM})$. Data from Shropshire et al. (2007).

${ }^{3}$ Dry Storage. Low cost assumes \$100/kgHM); high cost assumes (\$300/kgHM). Data from Shropshire et al. (2007).

${ }^{4}$ Land Transportation. Low cost assumes $\left.\$ 68.5 / \mathrm{kgHM}\right)$; high cost assumes (\$102.1/kgHM). Data from Shropshire et al. (2007).

${ }^{5}$ Sea Transportation. Costs based on very little available information for SNF transport on purpose-built ships. Low cost uses unit cost of $\$ 150 / \mathrm{kgHM}$, which assumes $\$ 5$ million per shipment and 34 tHM per shipment. High unit cost of $\$ 300 / \mathrm{kgHM}$ assumes \$10 million per shipment and 34 tHM per shipment.

\subsection{Status Quo (De-facto Acceptance of Enrichment Programs)}

The NPT does not currently preclude either Brazil or Argentina from further development of uranium enrichment technology; even if Brazil/Argentina were to eventually implement the AP, they would still not be precluded from pursuing enrichment technology. One policy option is to actively follow enrichment program developments in these countries, but to respond only when and if necessary.

As discussed previously, the annual requirements for enriched uranium by these countries in the near future is not sufficient to support economically-competitive indigenous enrichment plants. If the intent of these countries is only to provide for indigenous needs, then having domestic enrichment plants can only be justified as a means to provide assurance of nuclear fuel supply (Cabrera-Palmer and Rothwell 2008), which is consistent with respective national policies to be self-sufficient in nuclear fuel production.

Perhaps recognizing the large costs associated with developing separate, indigenous nuclear capabilities, and to further demonstrate that their nuclear programs are for peaceful uses only, Brazil and Argentina recently established a bi-national commission to explore further areas of nuclear cooperation between the two nations. One specific objective of this commission is to establish a bi-national company for uranium enrichment (Fiori 2008). While it is unclear at this time what the goals of this bi-national company will be, it is possible that ultimately the Resende plant could be transferred to this company and 
agreements reached to supply Argentina's enriched uranium requirements. ${ }^{14}$ If this happens, the foundation for a regional/international uranium enrichment center will have been established.

Ultimately, Brazil could then become a non-traditional source of enrichment services, including regional supplier of enrichment should other South American or Latin American countries pursue nuclear power. Brazil's own enrichment requirements are projected to be about 1,400,000 SWU/year by about 2025 based on current nuclear power expansion plans. Should Brazil decide to build a 3 million SWU/year or larger plant, there would not be a need for government subsidies since their enrichment technology appears to be scalable to meet world market prices. The cost per SWU for such a facility would be approximately $\$ 65$ per SWU. Only the fully depreciated Russian enrichment plants are cheaper. However, as stated earlier, the Brazilian constitution would need to be amended to allow the export of enriched uranium, although it is unclear if the export limitation only applies to Brazilian-mined uranium or to uranium imported for enrichment also.

Should Brazil pursue a policy of exporting enriched uranium, an appropriate U.S. government response would be to insist on development and implementation of an improved Safeguards approach for their enrichment plant. The current safeguards approach developed under the Hexapartite Safeguards Project (HSP) should not be merely extended to enrichment services provided by new suppliers. At a minimum, the well-understood weaknesses of the verification regime must be revisited and strengthened. To be accepted by Brazil, new safeguards measures and technologies would need to be accepted as a norm in all operating plants including Urenco facilities. Without these new measures, the latent risk associated with weak safeguards verification on enrichment facilities will continue to expand. The U.S. government should continue investments in improvements to the Safeguards approach and engage technology holding state governments on updates to the approach. The IAEA will not be able to sufficiently alter the HSP approach without technology holding state consensus - the Urenco states being preeminent in that process.

\subsection{Recommendations}

We do not believe there is a need for the United States to take immediate proactive actions responding to Brazil's and Argentina's enrichment programs. Both countries are in the near term preoccupied with constructing and expanding existing fuel production capacity to meet indigenous fuel production requirements. However, the following activities are suggested:

- Monitor for amendments to Brazil's constitution that would allow export of uranium. An amendment to the constitution to allow such exports is a flag that export of enriched uranium may be under consideration.

\footnotetext{
${ }^{14}$ Brazil and Argentina would likely make a joint plant subject to full peaceful use agreement, but Brazil might technology limit Argentina in the arrangement (it may not share its technology) and reserve the right to build a small ancillary facility for naval use. In this way, Brazil gets the best of all worlds: a partner to reduce financial risk on the commercial side and support for its navy program.
} 
- Engage Brazil and Argentina to determine if there is any common ground for an RFS\&S arrangement as an option. It is expected that Brazil may have little interest in such an arrangement due to its nuclear navy ambitions. However, Argentina may have an interest given its small needs for enrichment services. Argentina may especially be enticed by an offer of an ownership share in a U.S.-based international enrichment center.

- Consider developing criteria for influencing the structure of a multinational enrichment plant in Brazil, should Brazil decide to pursue exporting enriched uranium. Criteria for not opposing such a plant might include being a signatory of the AP, implementing an improved Safeguards approach (see bullet below), and requirements for operational oversight by the multinational partners.

- Actively develop an improved Safeguards approach and technology for enrichment plants beyond the HSP standard as currently exercised in Urenco facilities. Work to make this new standard the accepted norm for all operating enrichment plants including any new plants, in Brazil or Argentina. 


\subsection{References}

Asteriscos T. 2007. Dioxitek: Nueva planta de dióxido de uranio. Accessed December. 11, 2007 at http://www.asteriscos.tv/negocios-570.html.

BBC News. 2007. “"Brazil” to revive nuclear project.' Accessed July 18, 2007 at http://news.bbc.co.uk/2/hi/americas/6290234.stm.

Cabrera-Palmer B, and G Rothwell. 2008. "Why is Brazil enriching uranium.” Energy Policy, Volume 36, Issue 7, pp. 2570-2577.

CIA - Central Intelligence Agency. 2008. "CIA Factbook: Brazil.” Accessed February 19, 2008 at https://www.cia.gov/library/publications/the-world-factbook/geos/br.html\#Econ.

Defesanet, December 29, 2005. Urânio produzido em escala industrial, Accessed April 16, 2008 at http://www.defesanet.com.br/energia/cb nuclear.htm.

DOE 2001. World Cumulative Spent Fuel Projections by Region and Country, May 1, 2001, U.S. Department of Energy. Accessed May 19, 2008 at http://www.eia.doe.gov/cneaf/nuclear/page/forecast/cumfuel.html.

EIA - Energy Information Agency. 2007. U.S. Department of Energy. International Energy Outlook 2007. Accessed February 19, 2008 at www.eia.doe.gov/oiaf/ieo/index.html.

EIA - Energy Information Agency. 2008. U.S. Department of Energy. Annual Energy Outlook 2008. Accessed July 18, 2008 at http://www.eia.doe.gov/oiaf/aeo/.

European Commission. 2003. "World energy, technology and climate policy outlook." Community Research. Accessed April 3, 2008 at http://ec.europa.eu/research/energy/pdf/weto_final_report.pdf.

Fiori M. 2008. "Brazil and Argentina Create Nuclear Miniclub to Enrich Uranium.” Brazzil Magazine. Accessed May 19, 2008 at http://www.brazzilmag.com/content/view/9143/1/.

Goldletter . December 2005. UraniumStock of the Month. Goldletter International, Castricum, the Netherlands.

IEA - International Energy Agency. 2008. "Argentina: Statistics.” Accessed January 24, 2008 at http://www.iea.org/Textbase/stats/countryresults.asp?COUNTRY CODE=AR\&Submit=Submit.

IEA - International Energy Agency. 2006. World Energy Outlook 2006. Accessed October 30, 2008 at http://www.worldenergyoutlook.org/docs/weo2006/Brazil.pdf.

INB - Industrias Nucleares do Brazil. 2007a. FCN Nuclear Fuel Factory - Conversion, Fabrica de Combustivel Nuclear. Accessed October 18, 2007 at

http://www.inb.gov.br/english/resendeReconversao.asp.

INB - Industrias Nucleares do Brazil. 2007b. FCN Nuclear Fuel Factory - Pellets, Fabrica de Combustivel Nuclear. Accessed October 18, 2007 at http://www.inb.gov.br/english/resendePastilhas.asp. 
INB - Industrias Nucleares do Brazil. 2007c, FCN Nuclear Fuel Factory - Fuel Elements Component and Assembly, Fabrica de Combustivel Nuclear. Accessed October 18, 2007 at http://www.inb.gov.br/english/resendeElemento.asp.

INB - Industrias Nucleares do Brazil. 2007d. INB Caetité - Uranium Mining and Milling. Accessed October 17, 2007 at http://www.inb.gov.br/english/caetite.asp.

Jinchuk D. 2005. Present \& Future of Nuclear Technology in Argentina, Latin American Section, American Nuclear Society (LAS/ANS) Conference, "Reactivation of Nuclear Power Plants Construction in Latin America,” June 13-15, 2005, Rio de Janeiro, Brazil.

Jornal da Ciencia. 08 de Maio de 2006. "Brasil inaugura unidade para enriquecer urânio." Accessed April 16, 2008 at http://www.jornaldaciencia.org.br/Detalhe.jsp?id=37326.

Long G. 2007. "Strapped for Energy, Chile Looks at Nuclear Option,” March 12, 2007. Reuters News Service. Accessed February 7, 2008 at http://www.planetark.org/dailynewsstory.cfm/newsid/40789/story.htm.

Mercopress. 2006. Brazil plans to build seven nuclear reactors. Accessed October 23, 2006 at http://www.mercopress.com/vernoticia.do?id=9036\&formato=HTML.

NAC International. 2007. "The Outlook for Sustaniably and Cost of Nuclear Fuel Supply.” Nuclear Fuel Market Issues and Insights 2007. Accessed February 21, 2008 at http://www.nacworldwide.com/pdf/NFMII\%202007-April07CAR.pdf.

NEA - Nuclear Energy Agency. 2007. "Mexico.” Accessed February 20, 2008 at http://www.nea.fr/html/general/profiles/mexico.html.

NEA/IAEA - Nuclear Energy Agency and International Atomic Energy Agency. 2005. Uranium 2005: Resources, Production and Demand, Organization for Economic Co-operation and Development (OECD).

NEI - Nuclear Engineering International. 2007. Resende Developments, June 2007, pp. 24-26.

NTI. September 2007. Argentina Profile. Accessed February 18, 2008 at http://www.nti.org/e_research/profiles/Argentina/index.html.

Pesquisa FAPESP. 2007. The submarine that provides light, Edition 139. September 2007. Accessed June 13, 2008 at http://www.revistapesquisa.fapesp.br/?art=2038\&bd=1\&pg=1\&lg=en.

PROS - Professional Reactor Operator Society. 2007. Angra III construction could re-start year-endBrazil. Accessed August 7, 2007 at http://www.nucpros.com/?q=node/2166.

PTO - Physics Today.Org. February 2006. "Stronger Future for Nuclear Power." Accessed February 20, 2008 at http://www.physicstoday.org/vol-59/iss-2/p19.html.

Reuters. 2007a. Canada to help Argentina to build nuclear reactor. Accessed December 7, 2007 at .http://uk.reuters.com/article/oilRpt/idUKN2742267420070727.

Reuters. 2007b. "Mexico has three bids to upgrade nuclear plant." Accessed February 2, 2008 at http://uk.reuters.com/article/oilRpt/idUKN1920567620070120. 
Rohter L and J Forero. 2005. "Venezuelan leader eager to start nuclear program.” International Herald Tribune. Accessed February 20, 2008 at http://www.iht.com/articles/2005/11/27/news/chavez.php.

Rothwell G and C Braun. 2008. "International Uranium Enrichment Supply.” Submitted to Arms Control Today. Stanford University working paper.

Shropshire DE, KA Williams, WB Boore, JD Smith, BW Dixon, M Dunzik-Gougar, RD Adams, and D Gombert. March 2007. “Advanced Fuel Cycle Cost Basis.” INL/EXT-07-12107, Idaho National Laboratory, Idaho Falls, Idaho.

Terça-feira, 9 maio de 2006. “Auto-suficiência nuclear”. O Estado De S. Paulo. Accessed April 16, 2008 at http://www.estado.com.br/editorias/2006/05/09/edi113560.xml.

The Economist. 2007. Caught Short; Argentina, Vol. 383, Iss. 8533, pg. 58, London, United Kingdom.

thestar.com. 2008. Nuclear revival bumps against atrophy. Accessed May 8, 2008 at http://www.thestar.com/Business/article/420941.

Turner, Mark. 2008. “Chile: Facing a Severe Energy Crisis.” Latin America EconoMonitor. Accessed February 21, 2008 at http://www.rgemonitor.com/latam-monitor/604/chile_facing_a severe_energy_crisis.

UIC - Uranium Information Center. 2007a. "Nuclear Power in Argentina.” Nuclear Issues Briefing Paper 96. Accessed: February 18, 2008 at http://www.uic.com.au/nip96.htm.

UIC - Uranium Information Center. October 2007b. "Uranium Enrichment." Nuclear Issues Briefing Paper 33. Accessed February 18, 2008 at http://www.uic.com.au/nip33.htm.

UxC - The Ux Consulting Company, LLC. 2008 . "UxC Nuclear Fuel Price Indicators." Accessed February 18, 2008 at http://www.uxc.com/review/uxc Prices.aspx.

World Bank. 2008. Benchmarking of the Electricity Distribution Sector in the Latin America and Caribbean Region 1995-2005. Accessed January 29, 2008 at

http://info.worldbank.org/etools/lacelectricity/countryscorecard.asp? country_id=2\&gr1=1\&gr2=1\&gr3=1 $\underline{\text { \&selline }}=$.

World Energy Council. 2007. 2007 Survey of Energy Resources. Accessed January 28, 2008 at http://www.worldenergy.org/documents/ser2007 final online version 1.pdf.

WNN - World Nuclear News. June 4, 2008. Suez buys stake in Georges Besse II enrichment plant. Accessed June 4, 2008 at http://www.world-nuclear-news.org/C-

Suez buys stake in Georges_Besse II enrichment plant0406084.html?.jmid=12181\&j=123384611\&utm source=JangoMail\&utm medium=Email\&utm campai gn $=$ WNN+Daily $+4+$ June $+2008+\% 28123384611 \% 29 \&$ utm content $=$ steve $\% 2$ Eshort $\% 40$ pnl $\% 2$ Egov.

WNA - World Nuclear Association. June 2007. Nuclear Power in Brazil. Accessed October 16, 2007 at http://www.world-nuclear.org/info/inf95.html. 


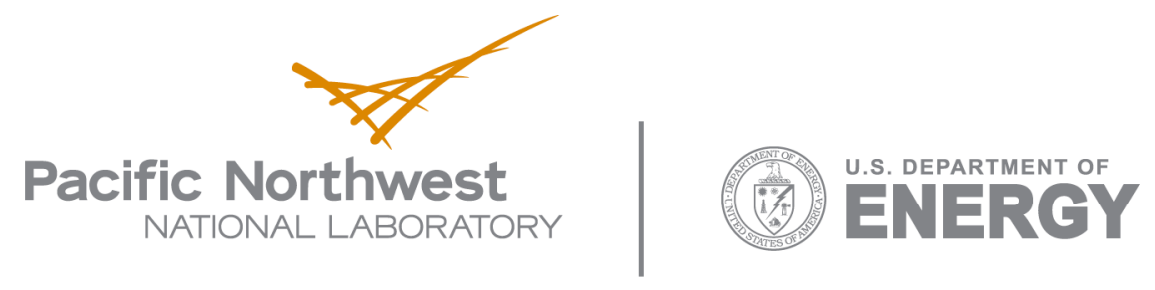

902 Battelle Boulevard

P.O. Box 999

Richland, WA 99352

1-888-375-PNNL (7665)

www.pnl.gov 